Evirominental Science.

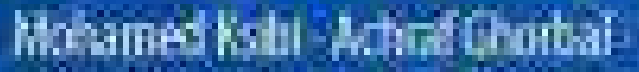

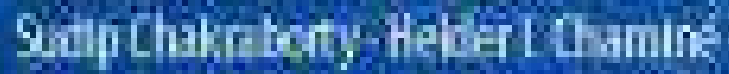

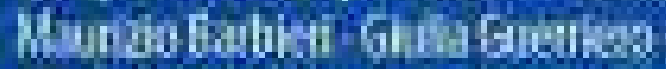

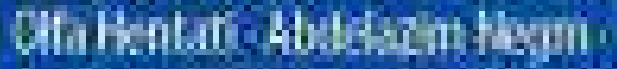

Ansybing

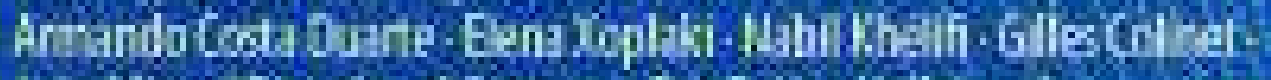

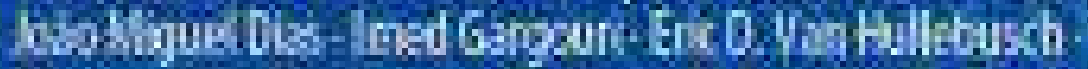

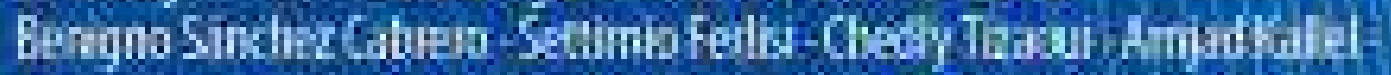

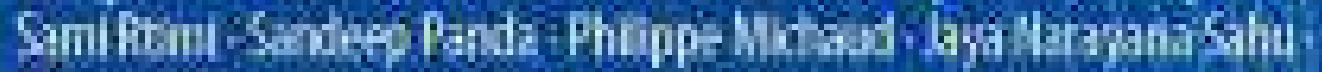

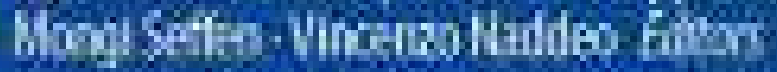

Recent Advances

in Environmental

Science from the Euro-

Mediterranean and

Surrounding Regions

(2nd Edition)

Proceedings of 2nd Euro-Mediterranean

Conference for Environmental

Integration (EMCEL-2), Tunisia 2019

요 Springer 


\title{
Environmental Science and Engineering
}

\author{
Environmental Science
}

\section{Series Editors}

Ulrich Förstner, Technical University of Hamburg-Harburg, Hamburg, Germany

Wim H. Rulkens, Department of Environmental Technology, Wageningen,

The Netherlands

Wim Salomons, Institute for Environmental Studies, University of Amsterdam, Haren, The Netherlands 
The protection of our environment is one of the most important challenges facing today's society. At the focus of efforts to solve environmental problems are strategies to determine the actual damage, to manage problems in a viable manner, and to provide technical protection. Similar to the companion subseries Environmental Engineering, Environmental Science reports the newest results of research. The subjects covered include: air pollution; water and soil pollution; renaturation of rivers; lakes and wet areas; biological ecological; and geochemical evaluation of larger regions undergoing rehabilitation; avoidance of environmental damage. The newest research results are presented in concise presentations written in easy to understand language, ready to be put into practice.

More information about this subseries at http://www.springer.com/series/3234 
Mohamed Ksibi - Achraf Ghorbal - Sudip Chakraborty • Helder I. Chaminé - Maurizio Barbieri • Giulia Guerriero • Olfa Hentati - Abdelazim Negm • Anthony Lehmann • Jörg Römbke - Armando Costa Duarte - Elena Xoplaki • Nabil Khélifi • Gilles Colinet • João Miguel Dias • Imed Gargouri • Eric D. Van Hullebusch • Benigno Sánchez Cabrero • Settimio Ferlisi • Chedly Tizaoui • Amjad Kallel • Sami Rtimi • Sandeep Panda • Philippe Michaud - Jaya Narayana Sahu • Mongi Seffen • Vincenzo Naddeo

Editors

\section{Recent Advances in Environmental Science from the Euro-Mediterranean and Surrounding Regions (2nd Edition)}

Proceedings of 2nd Euro-Mediterranean Conference for Environmental Integration (EMCEI-2), Tunisia 2019 


\section{Editors}

See next page

ISSN 1863-5520

ISSN 1863-5539 (electronic)

Environmental Science and Engineering

ISSN 1431-6250

ISSN 2661-8222 (electronic)

Environmental Science

ISBN 978-3-030-51209-5

https://doi.org/10.1007/978-3-030-51210-1

ISBN 978-3-030-51210-1 (eBook)

(C) The Editor(s) (if applicable) and The Author(s), under exclusive license to Springer Nature

Switzerland AG 2021

This work is subject to copyright. All rights are solely and exclusively licensed by the Publisher, whether the whole or part of the material is concerned, specifically the rights of translation, reprinting, reuse of illustrations, recitation, broadcasting, reproduction on microfilms or in any other physical way, and transmission or information storage and retrieval, electronic adaptation, computer software, or by similar or dissimilar methodology now known or hereafter developed.

The use of general descriptive names, registered names, trademarks, service marks, etc. in this publication does not imply, even in the absence of a specific statement, that such names are exempt from the relevant protective laws and regulations and therefore free for general use.

The publisher, the authors and the editors are safe to assume that the advice and information in this book are believed to be true and accurate at the date of publication. Neither the publisher nor the authors or the editors give a warranty, expressed or implied, with respect to the material contained herein or for any errors or omissions that may have been made. The publisher remains neutral with regard to jurisdictional claims in published maps and institutional affiliations.

This Springer imprint is published by the registered company Springer Nature Switzerland AG

The registered company address is: Gewerbestrasse 11, 6330 Cham, Switzerland 


\section{Editors}

Mohamed Ksibi

High Institute of Biotechnology

University of Sfax

Sfax, Tunisia

Sudip Chakraborty

University of Calabria

Rende, Cosenza, Italy

Maurizio Barbieri

Università degli Studi di Roma

Roma, Roma, Italy

Olfa Hentati

High Institute of Biotechnology

University of Sfax

Sfax, Tunisia

Anthony Lehmann

University of Geneva

Genève, Geneve, Switzerland

Armando Costa Duarte

Centre for Environmental+Marine Studies

University of Aveiro

Aveiro, Portugal

Nabil Khélifi

Springer Nature

Heidelberg, Baden-Württemberg, Germany

João Miguel Dias

University of Aveiro

Aveiro, Portugal

Eric D. Van Hullebusch

Institut de Physique du Globe de Paris

Université de Paris

Paris, France

Settimio Ferlisi

Department of Civil Engineering

University of Salerno

Fisciano, Italy
Achraf Ghorbal

Appliquées et Technologies

Institut Supérieur des Sciences

Gabès, Tunisia

Helder I. Chaminé

School of Engineering (ISEP)

Polytechnic of Porto

Porto, Portugal

Giulia Guerriero

University of Naples

Naples, Italy

Abdelazim Negm

Faculty of Engineering, Water and Water

Structure Engineering Department

Zagazig University

Zagazig, Egypt

Jörg Römbke

ECT Oekotoxikologie $\mathrm{GmbH}$

Flörsheim am Main, Hessen, Germany

Elena Xoplaki

Department of Geography

Justus-Liebig-University Giessen

Gießen, Hessen, Germany

Gilles Colinet

Gembloux Agro-Bio Tech

University of Liège

Gembloux, Belgium

Imed Gargouri

Faculty of Medicine of Sfax

University of Sfax

Sfax, Tunisia

Benigno Sánchez Cabrero

FOTOAIR-CIEMAT

Madrid, Madrid, Spain

Chedly Tizaoui

College of Engineering

Swansea University

Swansea, UK 
Amjad Kallel

Sfax National School of Engineering

University of Sfax

Sfax, Tunisia

Sandeep Panda (iD

Department of Mining Engineering

Suleyman Demirel University

Isparta, Turkey

Jaya Narayana Sahu

Institute of Chemical Technology

University of Stuttgart

Stuttgart, Baden-Württemberg, Germany

Vincenzo Naddeo

SEED DICIV

University of Salerno

Fisciano, Italy
Sami Rtimi

Swiss Federal Institute of Technology

Lausanne, Switzerland

Philippe Michaud

Université Clermont Auvergne, Polytech Aubière, France

Mongi Seffen

High School of Science and Technology University of Sousse

Sousse, Tunisia 


\section{Preface}

The Euro-Mediterranean and surrounding regions are currently facing accelerating environmental degradation. In the context of fast population growth, developing living standards, modernization and rapid industrialization, environmental challenges will continue and even be exacerbated in the years to come. These challenges reinforce the need to stimulate the environmental integration process by including environmental awareness, assessment, remediation and mitigation in concrete cooperative projects in the various sectors, and, most importantly, by highlighting the importance to decision-makers from the relevant sectors of integrating environmental considerations into their activities.

The integration of environmental concerns into policy decisions (i.e. environmental integration) must be intensified in order to move towards sustainable development. This is in line with the vision and plan of the European Commission for the Environment and other official organizations whose mission is to protect, preserve and improve both shores of the Euro-Mediterranean environment and their natural resources for present and future generations to ensure prosperity and social cohesion.

To stimulate the environmental integration process, it is the responsibility of scientists to consider opportunities to highlight research into potential solutions for environmental concerns and protection requirements based on innovative approaches that contribute to the preservation of a sustainable environment in the region.

In this context, the best contributions to the 2nd Euro-Mediterranean Conference on Environmental Integration (EMCEI-2019: www.emcei.net) were selected for this edited volume in order to emphasize the importance of the environmental integration process by considering the latest outcomes from interdisciplinary research (natural sciences, technology and engineering, and social sciences) with a broader focus on solution-based sustainability research, combined with a regional dimension: the Euro-Mediterranean area (which encompasses all the countries surrounding the Mediterranean) to bring recommendations and solutions for many common environmental issues, as well as mutual lessons learned.

Topics covered include approaches and methods for environmentally sustainable innovation; environmental risk assessment; bioremediation; eco-toxicology; water quality management; management of natural resources, including water resources 
and georesources; renewable energy; waste valorization and management; sustainable marine and coastal area management; geo- and natural hazards such as earthquakes, landslides and others; geotechnical and geo-environmental engineering; remote sensing and GIS for geo-environmental investigations; the impact of natural and social environments on human health; among others.

In addition to the aforementioned, this environmental integration process in the Euro-Mediterranean region can only achieve its goals through the stimulation of initiatives that reduce the development gap between the two shores of the Mediterranean and that create new and closer political, economic, social, cultural and, in particular, scientific ties, founded on shared concerns which develop and integrate environmental research in the region.

In this context, Springer and the Editorial office of the Euro-Mediterranean Journal for Environmental Integration organized the second edition of EMCEI which was held in Sousse, Tunisia in October 2019 following the 1st EMCEI launched in 2017. In response to the conference's call for papers, more than 600 papers were submitted by authors from 58 different countries, demonstrating the global relevance of EMCEI. Following peer review, 373 papers from the geo- and bio-environmental sciences and engineering were ultimately accepted, thus making an essential contribution to the science and knowledge bases to promote a more sustainable environment for the Euro-Mediterranean region.

The short papers gathered in this volume offer an overview of current research on emerging and ongoing environmental issues and challenges and of how it applies to problems specific to the Euro-Mediterranean region and to surrounding regions so that a broader perspective on related and similar environmental challenges may be gained. Papers are categorized into thirteen broad sections to reflect the main topics addressed at the conference, namely:

1. Engineering applications for environmental management;

2. Process control, simulations and intensification for environmental management;

3. Ecotoxicology, environmental safety and bioremediation;

4. Biotechnology for environmental management;

5. Climate-change-related effects on the environment and ecological systems;

6. Natural resources, agriculture and the environment;

7. Smart technologies for environmentally friendly energy production;

8. Remote sensing and GIS for environmental monitoring and management;

9. Environmental impacts of natural hazards and environmental risk assessment;

10. Sustainable management of marine and coastal environments;

11. Sustainable management of the urban environment;

12. Sustainable management of the indoor and built environment;

13. Environmental-change-related impacts on human health.

Presenting a broad range of topics and results, the 2nd EMCEI offered a valuable opportunity for researchers and students to learn more about recent advances in environmental research initiatives in view of the accelerating environmental degradation of the Euro-Mediterranean region, which has made environmental and 
resource protection a dominant priority for sustainable development and societal welfare. We hope scientists and policy makers will find these contributions from the 2nd EMCEI useful in the search to understand and solve some of the most pressing environmental issues for the Mediterranean region.

Sfax, Tunisia

Gabes, Tunisia

Rende, Italy

Porto, Portugal

Roma, Italy

Naples, Italy

Sfax, Tunisia

Zagazig, Egypt

Geneva, Switzerland

Flörsheim am Main, Germany

Aveiro, Portugal

Giessen, Germany

Heidelberg, Germany

Liege, Belgium

Aveiro, Portugal

Sfax, Tunisia

Paris, France

Madrid, Spain

Salerno, Italy

Swansea, UK

Sfax, Tunisia

Lausanne, Switzerland

Isparta, Turkey

Aubière, France

Stuttgart, Germany

Sousse, Tunisia

Salerno, Italy

December 2019
Mohamed Ksibi

Achraf Ghorbal

Sudip Chakraborty

Helder I. Chaminé

Maurizio Barbieri

Giulia Guerriero

Olfa Hentati

Abdelazim Negm

Anthony Lehmann

Jörg Römbke

Armando Costa Duarte

Elena Xoplaki

Nabil Khélifi

Gilles Colinet

João Miguel Dias

Imed Gargouri

Eric D. Van Hullebusch

Benigno Sánchez Cabrero

Settimio Ferlisi

Chedly Tizaoui

Amjad Kallel

Sami Rtimi

Sandeep Panda

Philippe Michaud

Jaya Narayana Sahu

Mongi Seffen

Vincenzo Naddeo

Acknowledgements We are grateful to the authors for their significant contributions. We also wish to thank the conference scientific and technical committees for their valuable help in reviewing the papers. Lastly, our thanks go to the series editors of Environmental Science and Engineering for approving the publication of this volume of proceedings, and to the Springer team for their efficient management of the publication process. 


\section{About the 2nd Springer Conference of the Euro-Mediterranean Journal for Environmental Integration (EMCEI-2), Tunisia 2019}
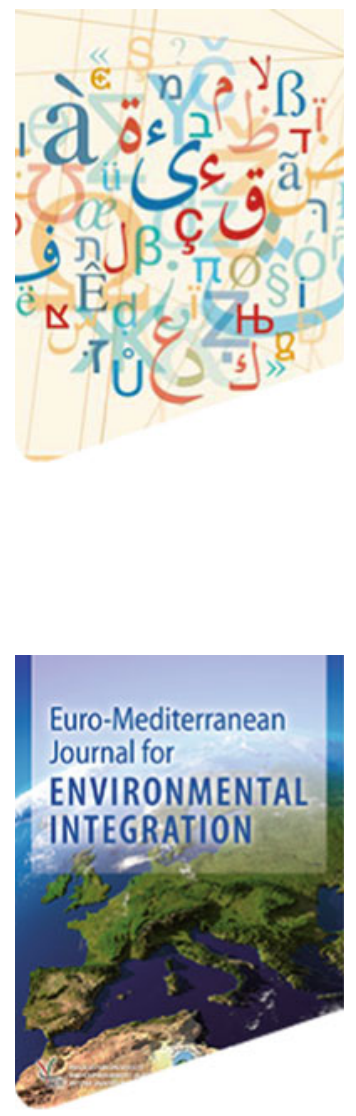

Currently, the Euro-Mediterranean region is facing not only significant political, economical and social challenges, but also an ever-growing environmental degradation that has made environmental and resource protection an increasingly critical issue. These issues have re-energized the debate on the Euro-Mediterranean integration process through concrete cooperative projects in many sectors, especially those concerned with environmental awareness, assessment and improvement. This integration process is intended to reduce the development gap between the northern and southern coasts of the Mediterranean and to create new and closer political, economical, social, cultural and, most importantly, scientific ties between these two shores founded on common concerns.

In this context, and with the specific aim to promote Euro-Mediterranean scientific partnership so as to develop and integrate environmental research and findings into the activities of related sectors in the region, a group of Euro-Mediterranean scientists have recently launched the Euro-Mediterranean Journal for Environmental Integration. This Springer journal, which started in 2016, has been now indexed in the Web of Science (ISI's ESCI database). It offers a scientific platform for presenting and discussing the latest advances in research with a focus on emerging environmental issues and challenges in the region. In particular, this first regional journal from the Euro-Mediterranean, encompassing all disciplines of the earth and environmental 


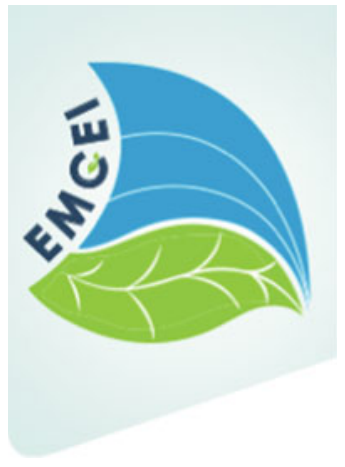

sciences, seeks to make societies and decision-makers from related sectors aware of the importance of integrating environmental considerations into their respective activities. In this context, the journal provides a scientific forum that promotes the exchange of knowledge and fosters collaborations to improve the consistency of environmental management efforts between the countries of the northern and southern shores of the Mediterranean.

To further strengthen Euro-Mediterranean environmental integration, the Editors of the Euro-Mediterranean Journal for Environmental Integration organize this year, in close collaboration with Springer, the 2nd Euro-Mediterranean Conference for Environmental Integration (EMCEI-2). The conference aims to gather new research contributions from all disciplines of earth and environmental sciences by Euro-Mediterranean scientists from diverse backgrounds, and thus makes an essential contribution towards ensuring that science and knowledge contribute to the promotion of a more sustainable environment for the Euro-Mediterranean region.

The scientific committee of the 2nd EMCEI invites research papers on all cross-cutting themes of the environmental sciences and engineering, with a main focus on the following thirteen conference tracks:

- Track 1. Engineering applications for environmental management

- Track 2. Process control, simulations and intensification for environmental management

- Track 3. Ecotoxicology, environmental safety and bioremediation

- Track 4. Biotechnology for environmental management

- Track 5. Climate-change-related effects on the environment and ecological systems

- Track 6. Natural resources, agriculture and the environment

- Track 7. Smart technologies for environmentally friendly energy production

- Track 8. Remote sensing and GIS for environmental monitoring and management

- Track 9. Environmental impacts of natural hazards and environmental risk assessment

- Track 10. Sustainable management of marine and coastal environments

- Track 11. Sustainable management of the urban environment

- Track 12. Sustainable management of the indoor and built environment

- Track 13. Environmental-change-related impacts on human health.

The dynamic four-day conference provided more than 400 attendees with opportunities to share their latest unpublished findings and learn the newest environment 
studies. The event also allowed attendees to meet and discuss with the journal's editors and reviewers.

More than 600 short contributing papers to the conference were submitted by authors from more than 70 countries. After a pre-conference peer-review process by more than 500 reviewers, 373 papers were accepted. These papers were published as chapters in the conference proceedings by Springer.

The conference proceedings consist of thirteen sections, each edited by the following group of Euro-Mediterranean Journal for Environmental Integration (EMJEI) editors and other guest editors:

\section{Section 1: Engineering Applications for Environmental Management}

Achraf Ghorbal: Institut Supérieur des Sciences Appliquées et de Technologie de Gabès, Tunisia

Mohamed Ksibi: High Institute of Biotechnology, University of Sfax, Tunisia Chedly Tizaoui: College of Engineering, Swansea University, United Kingdom Sami Rtimi: Swiss Federal Institute of Technology, Lausanne, Switzerland, Vincenzo Naddeo: University of Salerno, Italy

\section{Section 2: Process Control, Simulations and Intensification for Environmental Management}

Sudip Chakraborty: Università della Calabria, Italy

\section{Section 3: Ecotoxicology, Environmental Safety and Bioremediation}

Olfa Hentati: ISBS, University of Sfax, Tunisia

Achraf Ghorbal: Institut Supérieur des Sciences Appliquées et de Technologie de Gabès, Tunisia

Giulia Guerriero: University of Naples, Italy

Jörg Römbke: ECT Oekotoxikologie GmbH, Flörsheim am Main, Germany

Eric D. Van Hullebusch: Institut de Physique du Globe de Paris, Université de Paris, France

Sandeep Panda: Department of Mining Engineering, Suleyman Demirel University, Isparta, Turkey 


\section{Section 4: Biotechnology for Environmental Management}

Mohamed Ksibi: High Institute of Biotechnology, University of Sfax, Tunisia Eric D. van Hullebusch: Institut de Physique du Globe de Paris, Université de Paris, France

Philippe Michaud: Université Clermont Auvergne, Polytech Clermont Ferrand, Aubière, France

Olfa Hentati: ISBS, University of Sfax, Tunisia

Jörg Römbke: ECT Oekotoxikologie GmbH, Flörsheim am Main, Germany

Sandeep Panda: Department of Mining Engineering, Suleyman Demirel University, Isparta, Turkey

Giulia Guerriero: University of Naples, Italy

\section{Section 5: Climate-Change-Related Effects on the Environment and Ecological Systems}

Elena Xoplaki: Justus-Liebig-University Giessen, Germany

Nabil Khélifi: Springer, a part of Springer Nature, Heidelberg, Germany

\section{Section 6: Natural Resources, Agriculture and the Environment}

Helder I. Chaminé: School of Engineering (ISEP), Polytechnic of Porto, Portugal Maurizio Barbieri: Università degli Studi di Roma La Sapienza, Italy

Abdelazim Negm: Zagazig University, Egypt

Armando da Costa Duarte: University of Aveiro, Portugal

Gilles Colinet: Gembloux Agro Bio Tech, University of Liege, Belgium

\section{Section 7: Smart Technologies for Environmentally Friendly Energy Production}

Jaya Narayana Sahu: Universitat Stuttgart, Germany

Mongi Seffen: High School of Science \& Technology, University of Sousse, Tunisia 


\section{Section 8: Remote Sensing and GIS for Environmental} Monitoring and Management

Anthony Lehmann: Université de Genève, Switzerland

Nabil Khélifi: Springer, a part of Springer Nature, Heidelberg, Germany

\section{Section 9: Environmental Impacts of Natural Hazards and Environmental Risk Assessment}

Amjad Kallel: ENIS, University of Sfax, Tunisia

Helder I. Chaminé: School of Engineering (ISEP), Polytechnic of Porto, Portugal Settimio Ferlisi: University of Salerno, Italy

Maurizio Barbieri: Università degli Studi di Roma La Sapienza, Italy

\section{Section 10: Sustainable Management of Marine and Coastal Environments}

João Miguel Dias: University of Aveiro, Portugal

Giulia Guerriero: University of Naples, Italy

\section{Section 11: Sustainable Management of the Urban Environment}

Benigno Sánchez Cabrero: FOTOAIR-CIEMAT, Analysis \& Photocatalytic Treatment of Pollutants in Air, Madrid, Spain

Nabil Khélifi: Springer, a part of Springer Nature, Heidelberg, Germany

\section{Section 12: Sustainable Management of the Indoor and Built Environment}

Benigno Sánchez Cabrero: FOTOAIR-CIEMAT, Analysis \& Photocatalytic Treatment of Pollutants in Air, Madrid, Spain 


\section{Section 13: Environmental-Change-Related Impacts on Human Health}

Imed Gargouri: ENIS and Faculty of Medicine of Sfax, University of Sfax, Sfax, Tunisia 


\section{About the Conference Steering Committee}

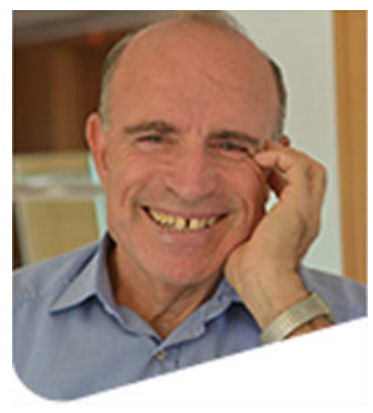

Honorary Co-Chair

Hamed Ben Dhia

Founder \& Advisory Board Member

Euro-Mediterranean Journal for Environmental Integration

ENIS, University of Sfax, Tunisia

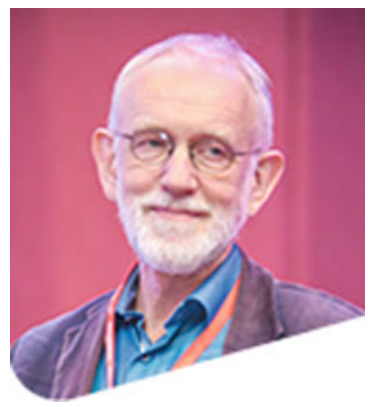

\section{Honorary Co-Chair}

Wolfgang Cramer

Advisory Board Member

Euro-Mediterranean Journal for Environmental Integration

CNRS, Aix-Marseille University, Aix-en-Provence, France

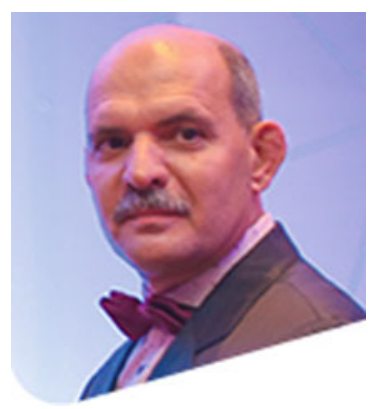

\section{General Co-Chair}

Mohamed Ksibi

Co-Editor-in-Chief

Euro-Mediterranean Journal for Environmental Integration

High Institute of Biotechnology, University of Sfax, Tunisia 


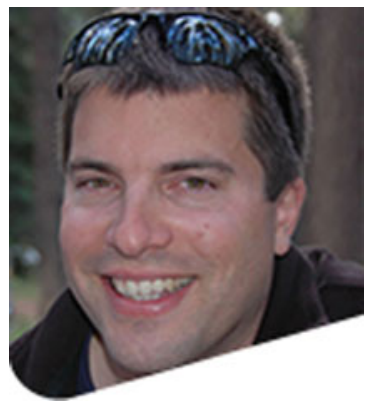

\section{General Co-Chair}

Markus Stoffel

Co-Editor-in-Chief

Euro-Mediterranean Journal for Environmental Integration

Institute for Environmental Sciences, University of Geneva, Switzerland

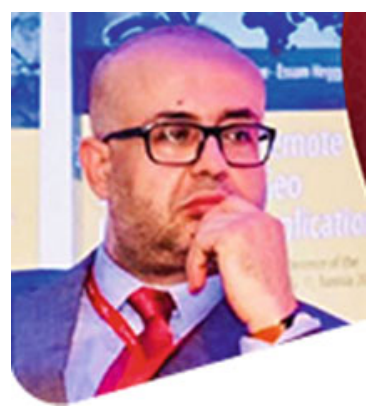

\section{Conference Supervisor}

Nabil Khélifi

Senior Publishing Editor, MENA program

Journal Publishing Manager

Euro-Mediterranean Journal for Environmental Integration

Springer, a part of Springer Nature, Germany

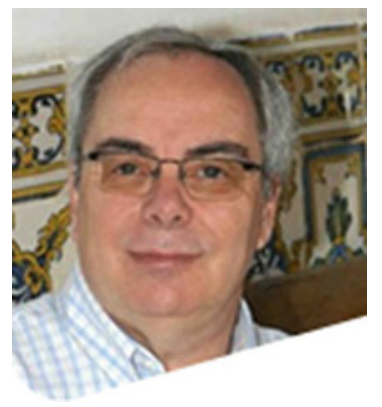

\section{Scientific Committee Chair}

Armando da Costa Duarte

Chief Editor-Track 6

Euro-Mediterranean Journal for Environmental Integration

University of Aveiro, Portugal

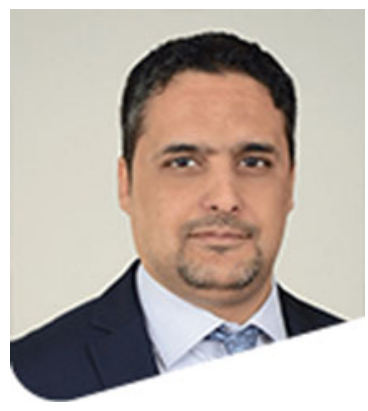

\section{Publications Co-Chair}

Sami Rtimi

Chief Editor-Track 1

Euro-Mediterranean Journal for Environmental Integration

Swiss Federal Institute of Technology, Lausanne, Switzerland 

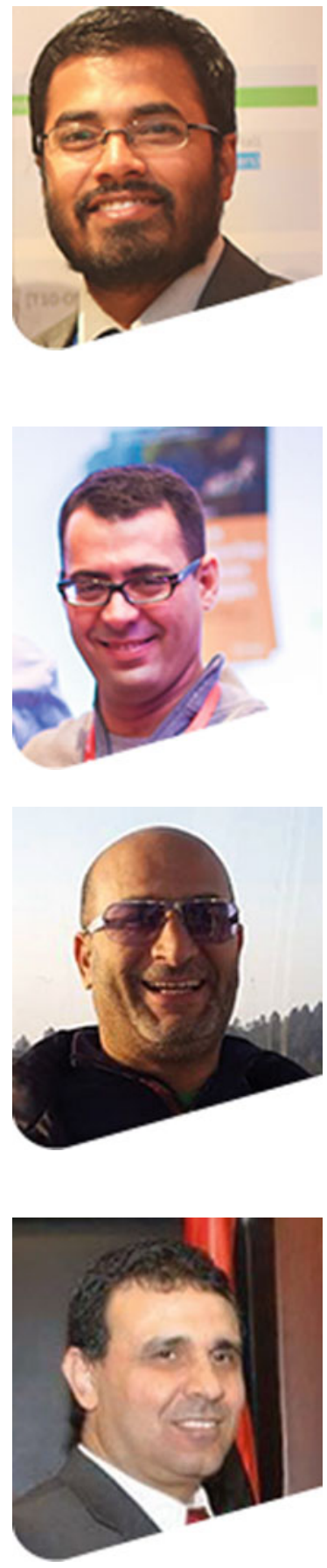

\section{Publications Co-Chair}

Sudip Chakraborty

Chief Editor-Track 2

Journal Development Editor

Euro-Mediterranean Journal for Environmental Integration

University of Calabria, Rende, Italy

\section{Program Co-Chair}

Achraf Ghorbal

Journal Development Editor

Euro-Mediterranean Journal for Environmental Integration

ISSAT, University of Gabes, Tunisia

\section{Program Co-Chair}

Amjad Kallel

Managing Editor

Euro-Mediterranean Journal for Environmental Integration

ENIS, University of Sfax, Tunisia

\section{Public Relations Co-Chair}

Alaa Abdelbary

Vice President-Arab Academy for Science,

Technology and Maritime Transport

Guest of Editorial Board of EMJEI

Alexandria, Egypt 


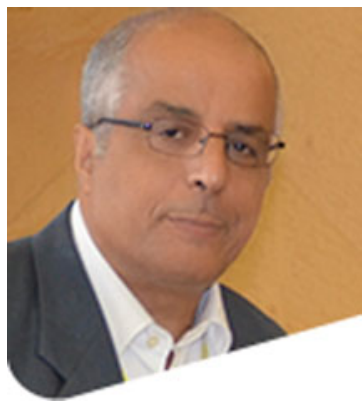

\section{Public Relations Co-Chair}

Mongi Seffen

Associate Editor

Euro-Mediterranean Journal for Environmental Integration

ESSTHS, University of Sousse, Tunisia

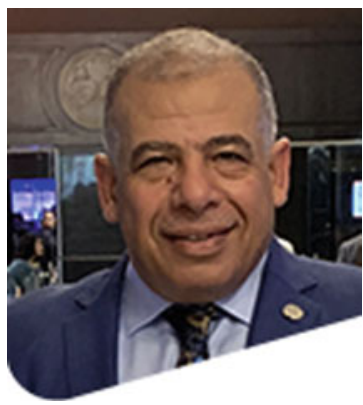

\section{Proceedings Editorial Manager}

Mourad Amer

Editor of Springer/IEREK ASTI Series

Guest of Editorial Board of EMJEI

IEREK, Alexandria, Egypt

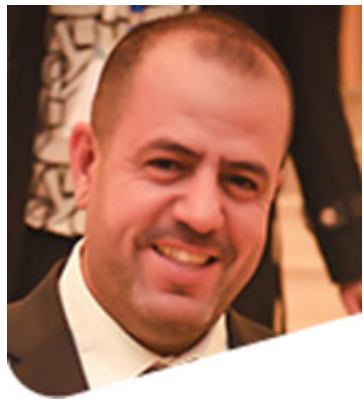

\section{Conference Manager}

Mohamed Sahbi Moalla

Journal Coordinator

Euro-Mediterranean Journal for Environmental Integration

ISET, University of Sfax, Tunisia 


\section{Contents}

Engineering Applications for Environmental Management:

Adsorption-Oriented Processes Using Conventional

and Non-conventional Adsorbents

Efficiency of Hybrid Process of Coagulation/Flocculation Followed

by Membrane Filtration for the Treatment of Synthetic Vegetable

Oil Refinery Wastewater ..................... 3

Ghofrane Louhichi, Philippe Moulin, Ahmed Ghrabi, and Imen Khouni

$\mathrm{Fe} /$ Clay Composite as Catalysts for Textile Wastewater

Treatment ............................ 9

Hajer Chargui, Khalil Lazaar, Hamza Elfil, Walid Hajjaji,

and Fakher Jamoussi

Iron Removal from Groundwater by Adsorption Process onto

Activated Carbon Obtained from Pinus Halepensis Cone Wastes ....

Zied Marzougui, Mohamed Damak, Leila Chaari, Sana Ghrab,

Abdelhamid Elaissari, and Boubaker Elleuch

Synthesis and Characterization of Activated Carbon from Pinus

Halepensis Cone Wastes: Adsorption Prediction as a Function

of Some Physicochemical Characteristics of Activated

Carbons

Zied Marzougui, Sana Ghrab, Mohamed Damak, Leila Chaari,

Abdelhamid Elaissari, and Boubaker Elleuch

Adsorption of Industrial Dye BzR from Aqueous Solution Using

Local Modified Clay

Kamel Ismet Benabadji, Zakarya Baouch, and Brahim Bouras

Adsorption-Desorption of Methylene Blue by Bentonite

from Aqueous Solution.

Nacer Dali, Réda Marouf, Malika Guerrab, Samra Djefal,

and Fatima Ouadjenia 
Removal of Disperse Dye from Aqueous Solution by Bottom Ash . . . .

Fatima Zohra Bennekrouf, Fatima Ouadjenia, and Réda Marouf

Experimental Study of the Removal of Rhodamine B from Aqueous

Solution by Adsorption onto Coffee Waste . . . . . . . . . . . . . .

Soumaya Larous, Abdeslam Hassen Meniai, Nadjet Boulkroune, and Nardjess Bouneb

Electrochemical Impedance Spectroscopy and Adsorption Study of Carbon Steel in 1 M HCl Solution Containing

2-(2-Methoxybenzylidene) Hydrazine-1-Carbothioamide

Hana Ferkous, Souad Djellali, Rachid Sahraoui, Hamza Behloul,

Khaoula Saoud, and Alaaddin Çukurovali

Adsorption Efficiency of Graphene Oxide Toward Cyanine Dyes

with Different Alkyl Chain Lengths

Abeer Elsherbiny, Ali Gemeay, and Mohamed Salem

$\mathrm{Cu}$ (II) Ions Removal on Functionalized Cellulose Beads from

Tunisian Almond (Prunus Dulcis) Shell . . . . . . . . . . . . . . . . .

Najeh Maaloul, Paula Oulego, Manuel Rendueles, Achraf Ghorbal, and Mario Díaz

Dynamics Modelling of Multicomponent Metal Ions Removal onto Low-Cost Buckwheat Hulls

Elwira Tomczak and Wladyslaw Kaminski

Local Materials and Solid Waste (Sawdust) Valorization

in the Treatment of Industrial Synthetic Water Field

Youcef Touil, Houria Mesrouk, Widad Aouarib, Djamila Barka,

Mohamed Lamine Sekirifa, Mahfoud Hadj-Mahammed,

and Abdeltif Amrane

Cationic Dye Removal Using Alginate-Organobentonite

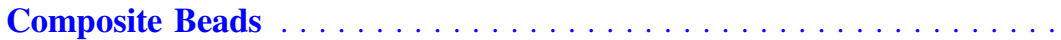

Asma Oussalah and Abdelhamid Boukerroui

Successive Removal of Methylene Blue and Congo Red

by Biomass-Based Beads from Aqueous Solutions

Hana Boubaker, Rim Ben Arfi, and Achraf Ghorbal

Malachite Green Removal Ability of a New Low-Temperature

Alkali-Treated Almond Shell Adsorbent.

Rim Ben Arfi, Khawla Guiza, Karine Mougin, and Achraf Ghorbal

Low-Cost Magnetic Adsorbents for Water Remediation

Nadia Chekalil, Salima Saidi-Besbes, and Abdelhamid Elaissari 
Optimization of Simultaneous Removal of Binary Toxic Antibiotic and Heavy Metal by Novel Biocomposite Beads: Modeling Study

Using Brouers-Sotolongo Family Equations . . . . . . . . . . . . . . .

Sarra Karoui, Rim Ben Arfi, María J. Fernández-Sanjurjo,

Avelino Nuñez-Delgado, Achraf Ghorbal,

and Esperanza Álvarez-Rodríguez

Application of Almond Shell-Based Materials for Aquatic Pollutants

Removal: A Mini-Review

Achraf Ghorbal and Rim Ben Arfi

Fabrication of Novel Keratin/Cellulose-Based Composites for Oils and Organic Solvents Absorption .

Khawla Guiza, Rim Ben Arfi, and Achraf Ghorbal

Study of the Influence of Some Parameters on the Efficiency

of Elimination of Zinc by Synthesized Na-Y Faujasite.

Hanane Bahaz, Abdelkader Hadj Seyd, Kerroumia Moulai,

Fatma Zohra Saifi, and Houria Naimi

Boron Sorption and Removal Using Hybrid Hydrogel Beads .

Joanna Kluczka, Alicja Kazek-Kęsik, and Gabriela Dudek

Engineering Applications for Environmental Management:

Advanced Wastewater Treatment Technologies, Recycling and Reuse

Reuse of Industrial Water at Mellitah Complex

Ahmed Mohammed Zaed, Issa M. Baghne, and Fawzi Elshawish

The Efficiency of Natural Decentralized Greywater Treatment

Systems in Resolving the Wastewater Problems in the Rural Areas

of Developing Countries

Abeer Albalawneh and Nicola Perilli

Physicochemical Characterization of Wastewater from the Mining

Activity: A Case Study from Boukhadra Mine (Algeria) . . . . . . . . . .

Fella Zenati and Adel Djellali

Fate of Selected Heavy Metals in a Biological Wastewater

Treatment System

Yahya El Hammoudani, Fouad Dimane, and Hossain El Ouarghi

Hydrothermal Carbonization of Olive Pomace Using Olive Mill

Wastewater as a Conversion Media

Ahmed Amine Azzaz, Mejdi Jeguirim, Camélia Ghimbeu,

Simona Bennici, Lionel Limousy, and Salah Jellali 
Ferritization-Based Treatment of Zinc-Containing Wastewater

Flows: Influence of Aeration Rates .

Bogdan Yemchura, Gennady Kochetov, Dmitry Samchenko, and Tatyana Prikhna

\section{Sonophotocatalytic Degradation of Endocrine Disrupting Chemical}

4-cumylphenol in the Presence of Inorganic Oxidant Species

in Aqueous Solution

Chiha Mahdi, Ahmedchekkat Fatiha, and Chamekh Hayet

Optimization of Indigo Dye Removal by Continuous

Electrocoagulation Process

Kamel Hendaoui, Fadhila Ayari, and Malika Trabelsi-Ayadi

Solid Particle Effect on Oxygen Transfer Rate in Electroflotation

Column

Maroua Mejri and Lassaad Ben Mansour

Influence of pH on Oxygen Transfer Rate in Electroflotation

Process .

Nadia Hajlaoui and Lassaad Ben Mansour

Pervaporation as an Alternative Desalination Method

Wladyslaw Kaminski, Elwira Tomczak, and Joanna Marszalek

Degradation of Orange G by Homogeneous Advanced Oxidation

Processes . . . . . . . . . . . . . . . . . . . . . . . . . . 207

Hayet Chamekh, Mahdi Chiha, and Fatiha Ahmedchekkat

Photooxidation of $\mathrm{NO}$ and $\mathrm{NO}_{2}$ with $\mathrm{TiO}_{2}$-Based Materials

Silvia Suárez, Alberto E. García de Castro, Mario Escobar, and Benigno Sánchez

Oxidation of Methylene Blue by Copper via a Heterogeneous

Fenton-Like Process . . . . . . . . . . . . . . . . . . . . . . . . . . .

Meriem Hamidani, Souad Djerad, and Lakhdar Tifouti

Engineering Applications for Environmental Management:

Optimization of Resources and Waste Management

Geotechnical Valorization of the Berhoum Area (Algeria) Geological Map for Preparing a Geotechnical Map for Construction . . . . . . . . . .

Amar Guettouche

Site Selection Criteria and Design for Landfills in an Arid Area with Shallow Groundwater Depth

Ali J. Chabuk, Nadhir Al-Ansari, and Jan Laue 
Environmental Impact Analysis Through the Industrial Lighting

Product Life Cycle

Shuyi Wang, Daizhong Su, You Wu, Shifan Zhu, Wentao Kuang, and Ming Ma

Novel Lignin-Reinforced Composites: Thermal Conductivity,

Mechanical Behavior, and Water Absorption.

Marwa Lahouioui, Rim Ben Arfi, Magali Fois, Laurent Ibos, and Achraf Ghorbal

Used Lamps Recycling in Geopolymers

Walid Hajjaji, Jihene Nouairi, Fernando Rocha, and Hamza Elfil

The Waste Valorization and the Circular Economy in Algeria:

An Overview

Fatiha Kazi Aoual-Benslafa and Kawther Touhami

Quantitative Estimation of Municipal Solid Waste in Sulaimaniyah

Governorate, Iraq . . . . . . . . . . . . . . . . . . . .

Karwan Alkaradaghi, Salahalddin Saeed Ali, Nadhir Al-Ansari, Tara Ali, and Jan Laue

Engineering Characteristics of Cement-Stabilized Lateritic Soils

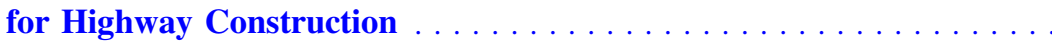

Omowumi Ademila

Optimization of Cutting Parameters Affecting the Surface Roughness of Al 6061 Dry Milling Machining Using Taguchi Method

S. Sulaiman, A. Aldeehani, M. Alhajji, and W. N. W. Isahak

Environmental Approach, Processing, and Valorization Solid Waste

Ceramic Breaks

Mustapha El Kanzaoui, Abdellah Guenbour, Ratiba Boussen, and Abdelowahed Hajjaji

Use of Waste Glass Powder as Partial Replacement of Cement

Mortar: Environmental Effects. . . . . . . . . . . . . . . . . . .

Abderrezak Khellou, Laid Mechri, and Sofiane Saggaï

Effect of Hydroxide Sludge Waste on Mechanical Properties

of Masonry Bricks . . . . . . . . . . . . . . . . . . . . .

Souad Kherbache, Nedjima Bouzidi, Salima Chebbi, Siham Aissou,

Karim Moussaceb, and Abdelkader Tahakourt

Contribution to the Study of Mechanical Behavior

of Granular Media

Souhila Fergani, Mohamed Chikhaoui, Patrick Pizette, and Ammar Nechnech 
The Use of Gold Ore Tailings from Amesmessa Mine as a Raw Material in the Ceramic Field

Amina Baziz, Nedjima Bouzidi, and Dolores Eliche-Quesada

Kinetic Study of Waste Tires by Thermogravimetric Analysis (TGA): Kissinger-Akahira-Sunose (KAS) Method

Rejeb Hiba, Berrich Betouche Emna, and Chahbani Mohamed Hachemi

Toxic Metal-Rich Extraction By-Product: Contamination

Assessment and Reprocessing

J. Nouairi, W. Hajjaji, F. Rocha, S. Mefteh, and M. Medhioub

Geoenvironmental Evaluation and Characterization of Near-Surface Subsoils for Sustainable Building Construction: An Integrated Approach . . . . . . . . . . . . . . . . . . . . . . . .

Kehinde D. Oyeyemi, Oluwarotimi M. Olofinnade,

Ahzegbobor P. Aizebeokhai, Anthony N. Ede, Michael A. Oladunjoye, Oluseun A. Sanuade, Theophilus A. Adagunodo, Opeyemi Joshua, and David O. Nduka

Solid Deposit Effects on the Pressure in Closed Pipes

Wahiba Mokrane

Mechanical Characteristics of Tunnel Concrete Lining Made with Dredged Sediment Subjected to High Temperatures

Fatiha Kazi Aoual-Benslafa and Kawther Touhami

Evaluation of the Mechanical and Environmental Properties of Self-Compacting Mortars with Raw Harbour Dredging Sediments (SCMs) . . . . . . . . . . . . . . . . . . . . . .

N. Philippe Ouedraogo, Frédéric Becquart, Mahfoud Benzerzour, and Nor-Edine Abriak

Engineering Applications for Environmental Management: Air Pollution Control

Evaluation of African Dust Events and Effect on $\mathbf{P M}_{10}$ Concentration in Tunisia .

Karim Bouchlaghem, Houda Chtioui, and Mohamed Hichem Gazzah

Comparing Methodologies for Emission Estimation of Fugitive Methane in Landfills

Nizar Bel Hadj Ali and Tarek Abichou

Compression Ratio Effect on the Performance and Emission of CI Engine Fueled with Waste Cooking Oil Methyl Ester and Diesel Blends at Constant RPM

Jeewan Vachan Tirkey, S. K. Shukla, and Amar Kumar Singh 
Contribution of the Spatio-temporal Evolution of Reduced Electric

Field on the Conversion of Nitrogen Oxides

Abdel Karim Ferouani, Fatiha Lassouani, Chawki Ougherb, Souhila Askri, and Mostefa Lemerini

A Regional Perspective of Environmental Impact Assessment

Research: A Bibliometric Mapping and Visualization . . . . . . . . .

Shaher Zyoud

Feasibility of Integrating (PV/T) Solar Collector in Tunisian

Households to Cover Thermal and Electric Building Needs

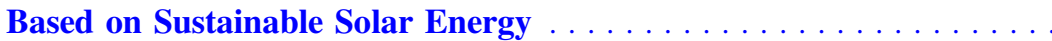

Majdi Hazami

Study of a Solar CombiSystem (SCS) Producing Thermal and Electric Energies in Tunisian Households . . . . . . . . . . . . . . . . . . .

Majdi Hazami, Farah Mehdaoui, and AmenAllah Guizani

Determination of Wood Emissivity Using Active Infrared

Thermography

Rui Pitarma and João Crisóstomo

Comparison Between Ventilation, Recirculation, and Duncle Cycles of Desiccant Cooling System in the Hot and Dry Weather of Gabes . . .

Sarra Belguith, Zina Meddeb, Romdhan Ben Slama, and Bechir Chaouachi

Process Control, Simulations and Intensification for Environmental Management

Enhanced Cyclohexane Oxidation Activity and Selectivity on New Supported Transition Metal Catalysts Based on Co and Ag . . . . . . .

Ritha Soulimane, Khaira Tafiani, Nawel Ameur, Redouane Bachir, and Sumeya Bedrane

Synthesis, Characterization, and Application in Liquid Phase Organic Oxidation of $\mathrm{LaFe}_{1-\mathrm{x}} \mathrm{Co}_{\mathrm{x}} \mathrm{O}_{3}$ Nanoparticles

Imen Jaouali, Noomen Moussa, Mohamed Faouzi Nsib,

Miguel Angel Centeno, and Ammar Houas

Effect of Urea-Hydrogen Peroxide Content on the Photocatalytic

Activity of Zinc Oxide Nanoparticles . . . . . . . . . . . . . . . . . .

Karima Ayeb, Noomen Moussa, Giuseppe Marci, Elisa Garcia-Lopez, and Mohamed Faouzi Nsib

Enhancement of the Compatibility Between Natural Rubber and Pineapple Leaf Microfibers for Better Stress Transfer

in Their Composite.

Budsaraporn Surajarusarn, Nuttapong Hariwongsanupab, Gautier Schrodj,

Samar Garreau, Karine Mougin, and Taweechai Amornsakchai 
Potential Applications of Zeolite Membranes . . . . . . . . . . .

C. Algieri

Extraction and Use of Lignin for Membrane Properties

Modification . . . . . . . . . . . . . . . . . . . . . .

Adel Zrelli, Walid Elfalleh, and Achraf Ghorbal

Optimized Functionalization of Industrial Waste for Oil Spill

Remediation

Sebastiano Candamano, Angelo Mazza, Fortunato Crea, and Sudip Chakraborty

Successful Use of Response Surface Methodology to Enhance the Degradation Efficiency of a Water Pollutant of Emerging

Concern

Andrei-Ionuț Simion, Raluca Maria Hlihor, and Lidia Favier

Oriented Membrane Processes for Selective Separation and

Recovery of Direct Red 80 and Methylene Blue Dyes from Textile

Wastewater ...........................

I. Mourtah, Z. Habibi, Y. Chaouqi, T. Eljaddi, N. Sefiani, L. Lebrun, and Miloudi Hlaïbi

Adsorption of Dyes from Aqueous Solutions onto Multi-functional PPy/CS Exfoliated Nanohybrid for Fashionable Layered Polymer

Nanocomposites . . . . . . . . . . . . . . . . . . . . . . . . .

Nehal A. Salahuddin, Hosny A. EL-Daly, Rehab G. El Sharkawy, and Beshoy T. Nasr

Application of Risk Analysis to Improve Environmental

Sustainability of Water in Construction Sites

Francesca Fornasari, Matteo Bo, Francesco Formisano, Federica Pognant, and Marina Clerico

The Concrete Degradation Caused by Ammonium Chloride Present in Coke Wastewater

Barbara Słomka-Słupik

Ternary Phase Equilibrium Data for Water/Acetic Acid/Solvent

(n-Hexane, n-Heptane) Systems

Nadjet Boulkroune, Abdeslam Hassen Meniai, Soumaya Larous, and Abdelhafid Talhi

Quality of Prediction for Spatiotemporal Covariance Models

Helmut Waldl

Thermodynamic Analysis and Simulation of the Absorption

Refrigeration System

Nihel Ben Zid, Nejib Hajji, and Mohammed El Ganaoui 
Behind the Mechanism of Chromium (VI) Removal and Reduction from Aqueous Solutions by Fungal Biomass Using a Bio-Inspired

Process Modelling and Optimization

Raluca Maria Hlihor, Elena Niculina Drăgoi, Mariana Diaconu,

Lidia Favier, Silvia Curteanu, and Maria Gavrilescu

Assessment of Groundwater Vulnerability to Pollutants by Electrical Resistivity Tomography at Mateur Plain, Northeastern Tunisia:

Preliminary Result

Chadia Riahi, Mohamed Khaled Bouzid, Romdhan Haddad, Adel Klai, and Kamel Regaya

Modelling Approach of the Biogeochemical Cycle on the Moroccan

Shallow Reservoir . . . . . . . . . . . . . . . . . . . . . .

Karima Khalil, Hanane Rhomad, Wafae Belokda, Hiba Ahdour,

Zainab Damsiri, and Khalid Elkalay

Assessment of Management Practices Impact on the Water Quality of the Béja River Watershed Using SWAT Model . . . . . . . . . . . . .

Dorsaf Ben Othman, Mohamed Fadhel Megdiche, and Moncef Gueddari

Ecotoxicology, Environmental Safety and Bioremediation:

Ecotoxicology

Heavy Metals in Estuarine Sediments: Chemical Bioavailability

and Toxicity Assessment.

Sofia E. Koukina and Nikolay V. Lobus

Ecological Risk Assessment of Trace Metal Pollution in an Urban

Agricultural Area of Yaoundé (Cameroon)

Amina Aboubakar, Ahmed Douaik, Yvette Clarisse Mfopou Mewouo,

Raymond Charly Birang A. Madong, Abdelmalek Dahchour,

and Souad El Hajjaji

Phytotoxicity of Copper and Zinc in Tomato Plants (Lycopersicon

Esculentum. Mill): Impact on Growth and Mineral Nutrition . . . . . . .

Abdelhafidh Hemeir, Ali Masmoudi,

and Houcine Abdelhakim Reguieg Yssaad

Persistence and Differential Survival of Fecal Indicator Bacteria in Boukourdane Waters . . . . . . . . . . . . . . . . . . . . . .

Siham Arab, Somia Hamil, and Abdeslam Arab

Bioaccumulation Assessment of Trace Metals by Three Main

Demersal Fish from Algerian Coast . . . . . . . . . . . . . . . . . . .

Inal Ahmed, Belkacem Yasmina, Benfares Redouane, Rouidi Samir,

Bachouche Samir, and Boulahdid Mostefa 
Ecotoxicological Requirements and Test Methods for the Evaluation of Wastes

Jörg Römbke

Histopathological Changes in the Hepatopancreas of Porcellio Laevis (Crustacea, Isopoda) After Exposure to $\mathrm{Cd}$ and $\mathrm{Zn}$ Mixture .

Chedliya Ghemari, Raja Jelassi, Hajer Khemaissia, Christophe Waterlot, Maryline Raimond, Catherine Souty-Grosset, Francis Douay, and Karima Nasri-Ammar

Responses of Orchestia Montagui (Amphipoda, Talitridae)

to Copper and Zinc Mixture

Raja Jelassi, Hajer Khemaissia, Chedliya Ghemari, Maryline Raimond, Catherine Souty-Grosset, and Karima Nasri-Ammar

Pollution-Related Decrease in the T-Cell Immune Response in a Wild Bird Species

Ayadi Tasnim, Hammouda Abdessalem, and Selmi Slaheddine

Phytotoxic Effect of Pollution on Young Olive Trees

(Olea europaea L.) .

Dhouha Frikha and Béchir Ben Rouina

Characterization and Ecotoxicological Assessment of Polycyclic

Aromatic Hydrocarbons in Soils from the Niger Delta,

Nigeria

Mutiu Adesina Adeleye, Ohiro Oziegbe, and Ouadadi Senouci

Acute and Sub-Lethal Toxicity of Aluminum on Developing

Zebrafish Embryos

Evangelia Gouva, Cosmas Nathanailides, Ioannis Paschos,

Fotini Athanassopoulou, and Ioannis S. Pappas

Mitochondria Dysfunction on Striatum After a Chronic Exposure to Pesticides Mixture in Rats . . . . . . . . . . . . . . . . . . .

Salim Gasmi, Brahim Ben Aicha, Rachid Rouabhi, Samira Boussekine, and Mohamed Kebieche

Comparative Growth of Cereal Species Under Lead Stress

Hana Souahi, Zina Gassarellil, Ahlem Gharbi, and Leila Meksem Amara

Ecotoxicology, Environmental Safety and Bioremediation:

Environmental Safety

Heavy Metals Spatial Distribution in Seawater, Suspended

Particulate Matter, and Sediments in Gabes Gulf (Tunisia) . . . . . . . . .

Dorra Gargouri, Annabi-Trabelsi Neila, Qusaie Karam, and Habib Ayadi 
Storage Facilities Reclamation Using Dredged Sediments from Waterways: Growing Media Formulation for Plants According to E.U ECOLABEL Framework . . . . . . . . . . . . .

Marie Lemay, Yannick Mamindy-Pajany, Nor-Edine Abriak, Afef Zouch, and Mohamed Ksibi

The Use of Armadillo Officinalis Duméril, 1816 (Crustacea, Isopoda) as a Tool for Trace Element Contamination Assessment . . . . . . . . . . Hajer Khemaissia, Raja Jelassi, Chedliya Ghemari, Maryline Raimond, Catherine Souty-Grosset, and Karima Nasri-Ammar

Assessment of Heavy Metals in Water from Lake Kivu, Rwanda . . . .

Alliance Nyiragatare, Valens Habimana, Tite Migabo,

Dieudonne Mutangana, Theoneste Muhizi, and Antoine Nsabimana

Investigation of Man-Caused Contaminated Sites in the Arctic

Region

Anastasiia Karnaeva, Olga Kulikova, Elena Mazlova, and Aleksey Buryak

The Mussel Mytilus Galloprovincialis: Nutritional Quality and Bioindicator of Availability of Radionuclides in the Marine Environment (Algerian Basin)

Yassine Guendouzi, Dina Lila Soualili, Mostefa Boulahdid,

Nabila Eddalia, Meriem Boudjenoun, and Abdelkader Noureddine

Sea Farms as a Safe and Sustainable Food Source: An Investigation on Use of Seaweeds for Liver Detoxification and Reduced DNA

Damage in Lates Calcarifer (Bloch, 1790).

Oladokun Sulaiman Olanrewaju, Anna De Maio, Eva Lionetti,

Anna Rita Bianchi, Dea Rabbito, Andrea Ariano, Fatima-Zahra Majdoubi, and Giulia Guerriero

Honeybees as Bioindicators in Environmental Monitoring:

Practical Applications and Open Online Course . . . . . . . . . . .

Luca Bolelli, Elida Nora Ferri, Stefano Sangiorgi, Claudio Porrini, Luca Ferrari, Marco Nenzioni, Roberto Colombo, Severino Ghini, and Stefano Girotti

Ecotoxicology, Environmental Safety and Bioremediation: Bioremediation

Praseodymium Recovery from Aqueous Solutions with a Low-Cost Fucus vesiculosus Algal-Based Material . . . . . . . . . . . . .

H. Demey and T. Mhadhbi

Elimination of Pollutants from Industrial Wastewater

by Phytoremediation

Sarra Badache, Nora Seghairi, and Naouel guerrouf 
Plant Growth Promoting and Heavy Metal-Tolerant Rhizobia from Algeria .

Mouloud Ghadbane, Laid Benderradji, Samir Medjekal, Hani Belhadj, and Harzallah Daoud

Assessment of Arbuscular Mycorrhizal Fungi Status and Rhizobium on Date Palm (Phoenix dactylifera L.) Cultivated in a $\mathbf{P b}$ Contaminated Soil 703

Mouloud Ghadbane, Samir Medjekal, Laid Benderradji, Hani Belhadj, and Harzallah Daoud

Larvicidal Activity of Lamiaceae and Lauraceae Essential Oils and Their Effects on Enzyme Activities of Culex pipiens $\mathbf{L}$.

(Diptera: Culicidae)

Fouzia Tine-Djebbar, Djemaa Dris, Radja Guenez, Samir Tine, and Noureddine Soltani

Applicability of Surfactant-Enhanced Remediation in Arctic

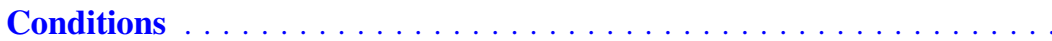

Olga Kulikova, Elena Mazlova, Tatiana Smirnova, and Anastasiia Karnaeva

The Study of Biotransformation Products and Microbiological Activity of Antibacterial Drugs In Vivo .

Nailya Ibragimova, Marina Lyu, Aitugan Sabitov, Saltanat Jumabayeva, and Roza Karzhaubayeva

A Novel Drug Delivery System for Amphotericin B to Treat Cutaneous Leishmaniasis

Nour Elhouda Benammar and Ahmed Hichem Hamzaoui

Native Bacteria from Djebel Onk Mine (Algeria) Exhibit Selective Adhesion onto Phosphate Ore . . . . . . . . . . . . . . . .

Hakim Rabia, Malek Ould Hamou, Katarzyna Kasperkiewicz,

Izabela Potocka, and Maria Augustyniak

Biotechnology for Environmental Management: Removal of Environmental Pollutants by Biological Processes

Expression of Mutated SapB-N99Y Keratinase in Bacillus subtilis DB430 and Its Attractive Properties for Soaking Hides and Skins in the Leather Processing Industry $\ldots \ldots \ldots \ldots \ldots \ldots$

Nadia Zaraî Jaouadi, Mouna Sahnoun, Hatem Rekik, Mouna Ben Elhoul, Haifa Khemir Ezzine, Neila Miled, Samir Bejar, and Bassem Jaouadi

Production and Characterization of Komagataeibacter xylinus SGP8 Nanocellulose for Its Application in the Removal of Cd Ions . . . . . . . . Amrik Bhattacharya, Ayesha Sadaf, R. P. Singh, and S. K. Khare 
Optimization of Pectin Extraction from Orange Peels

and Its Anti-proliferative Potential on HEp2 Cancer Cells.

Hadjira Hamai-Amara, Khalida Abdoun-Ouallouche, Assia Nacer-khodja,

Karima Abdelhafid, Abdelouafi Benmouloud, and Assia Djefal-Kerrar

Extraction and Valorization of Sericin for Textile Treatments .

Imene Belhaj Khalifa and Néji Ladhari

Biotechnological Properties of New Microbial Peroxidases for Lignin and Humic Acid Biodegradation and Biodeterioration .

Bassem Jaouadi, Khelifa Bouacem, Hatem Rekik, Nadia Zaraî Jaouadi, Samir Bejar, Rachid Annane, Abdelmalek Badis, and Amel Bouanane-Darenfed

Comparative Study of Cooked and Uncooked Food Waste Co-composting with Green Waste and Sewage Sludge:

A Case Study of Tunisia

Nour El Houda Chaher, Mehrez Chakchouk, Hadef Redjem, Abdallah Nassour, Michael Nelles, and Moktar Hamdi

Nitrogen Removal from Ink-Jet Textile Printing Wastewater by Autotrophic Biological Process: First Results at Lab

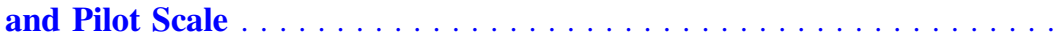

Giacomo Bellandi, Roberto Di Cosmo, Andrea Turolla, Micol Bellucci, Simone Visigalli, Glauco Menin, Martina Bargna, Giovanni Bergna, and Roberto Canziani

A Novel Approach for Stabilizing Heavy Metals in Municipal Solid Waste Incineration (MSWI) Fly Ash Using Waste Fishbone Hydroxyapatite (FB-HAP)

Amirhomayoun Saffarzadeh, Mitali Nag, Takeshi Nomichi, Takayuki Shimaoka, Hirofumi Nakayama, and Teppei Komiya

Preparation of Iron-Loaded Maritime Pine Tannin Resins for Arsenic Uptake from Water

Hugo Alexandre Mendes Bacelo, Cidália Maria de Sousa Botelho, and Sílvia Cristina Rodrigues dos Santos

Biotechnology for Environmental Management:

Bio-Adsorption Process

Removal of Phenol from Aqueous Solution by Coupling Alternating

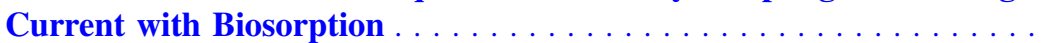
Amina Othmani, Aida Kesraoui, and Mongi Seffen

Novel Biosorbents from Tunisian Date Palm "Bouhattam" Seeds

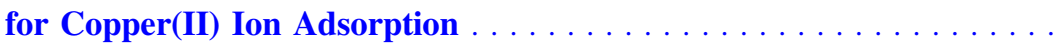

Najeh Maaloul, Paula Oulego, Manuel Rendueles, Achraf Ghorbal, and Mario Díaz 
Adsorption of Anionic Surfactant on Phragmites Australis:

Pretreatment and Reaction Mechanisms

Rania Dallel, Rochdi Baati, and Mongi Seffen

Treatment of Direct Yellow 106 by Fenton Process Using Taguchi

Method.

Nabila Boucherit, Mahmoud Abouseoud, Mohamed Barki,

and Lydia Adour

Oriented Membrane Processes for the Treatment and Recovery

of Vanadium Ions from Industrial Acidic Solutions . . . . . . . . . . . . . .

Imane Touarssi, Y. Chaouqi, I. Mourtah, T. El Jaddi, Sanaa Majid,

L. Lebrun, and M. Hlaïbi

Mg and Cd Biosorption by Native Bacteria From Djebel Onk Mine

(Algeria)

Hakim Rabia, Malek Ould Hamou, Katarzyna Kasperkiewicz,

Magdalena Skowronek, and Maria Augustyniak

An Eco-Friendly Alternative Biosorption of Heavy Metal Removal from Industrial Wastewater: Characterization and Application . . . . . .

Zied Marzougui, Mohamed Damak, Leila Chaari, Sana Ghrab, and Boubaker Elleuch

Removal of Hexavalent Chromium by Pleurotus Mutilus Biomass

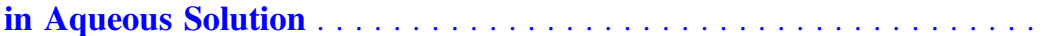

Ali Alouache, Ammar Selatnia, and Boubekeur Nadjemi

Effective Removal of Heavy Metal Ions from Wastewater

Using a New Magnetic PolyHIPE Monoliths

Zakaria Mokadem, Salima Saidi-Besbes, Geraldine Agusti,

and Abdelhamid Elaissari

Synthesis of Polyaniline/Pectin Biocomposite and Its Efficiency

as Adsorbent for Methylene Blue Removal

Souad Djellali, Amani Touati, Maya Kebaili, and Rachid Sahraoui

Biotechnology for Environmental Management: Drug Residues

Control and Microbial-Contamination Surveillance

Extraction of Drug Residuals from an Aqueous Solution

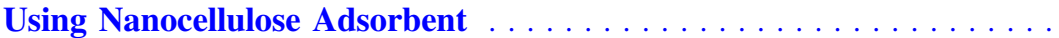

Yasmin Thaher, Shehdeh Jodeh, and Othman Hamed

The Treatment of Wastewater According to the Oriented Membrane Processes for the Extraction and Recovery of the Norfloxacin

Rkia Louafy, Sanae Tarhouchi, H. Mouadili, O. Kamal, K. Touaj,

L. Lebrun, and M. Hlaïbi 
Extraction Behaviors for Inorganic Arsenic Removal from Seaweed

(Gracilaria Fisheri) Using Food Additives

Charuwan Khamkaew

Detection of Hepatovirus a in Two Tunisian Wastewater Treatment

Plants . . . . . . . . . . . . . . . . . . . . .

Chourouk Ibrahim, Salah Hammami, and Abdennaceur Hassen

Performance of Laboratory Scale up-Flow Constructed Wetlands

for Tertiary Wastewater Treatment . . . . . . . . . . . . .

Narimen Baccari, Mona Lamine, and Moncef Khadraoui

Oriented Membrane Processes for the Treatment of Wastewater from the Pharmaceutical Industry Loaded with Paracetamol

Compound

Sanae Tarhouchi, Rkia Louafy, E. H. Atmani, K. Touaj, L. Lebrun, and M. Hlaïbi

Reversibility Effects of Salinity Stress in Lepidium Sativum: Growth,

Resistance State, and Management.

Chiraz Chaffei-Haouari, Hajer Bechedly, Tarek Slatni, and Houda Gouia

Climate-Change-Related Effects on the Environment and Ecological Systems

Comparison of the Atmospheric Attenuation of the Equatorial and Temperate Zones.

Abdelmoula Ben-tayeb, Mohammed Diouri, and Hanae Steli

Annual Precipitation Variability in Semi-Arid Area: The Wadi

Cheliff Case Study, Algeria $\ldots \ldots \ldots \ldots \ldots \ldots \ldots$

Mohammed Achite and Tommaso Caloiero

Estimation of the Mid and Late Century Extreme Summer Winds Over the Eastern Mediterranean from EURO-CORDEX Models . . . .

Stella Dafka, Andrea Toreti, Prodromos Zanis, Elena Xoplaki, and Jeurg Luterbacher

Evaluating Satellite-Derived Evapotranspiration Trends: A Case Study of the Marksovsky District of the Saratov Region (RF) . . . . . . .

Olga Ermolaeva, Anatoly Zeyliger, Liubov Molchanova, and Yujiu Xiong

Spatiotemporal Variability of Rainfall and Temperature

for the Dhidhessa River Basin (Ethiopia)

Gizachew Kabite Wedajo, Misgana Kebede Muleta, Berhan Gessesse, and Sifan Abera Koriche

Contribution to the Understanding of Rainfalls Occurring in Buenos Aires City (Argentina) Between 1960 and $2018 \ldots \ldots \ldots \ldots \ldots$ Marcelo L. Morales-Yokobori 
Effect of Physical Parameters on the Transparency of Ichkeul Lake's

Waters, North-East of Tunisia

Hajer Ouni, Mitsuteru Irie, Nabiha Ben M'barek, Jamila Tarhouni,

Nejla Tlatli-Hariga, and João Miguel Dias

Mapping of the Vulnerability to Pollution of El Oued Shallow

Aquifer in the Algerian Sahara

Boualem Bouselsal and Mohammed Ouarekh

The Impact of Climate Change on the Hydrological Characteristics and Water Availability of the Pamir Mountainrivers

Parviz Normatov, Rano Eshankulova, Inom Normatov, and Qodirjon Odinaev

Influence of Tillage Systems on Soil Bulk Density and Carbon

Dioxide Emissions in the Mediterranean Context . . . . . . . . . . . . .

Roua Amami, Khaled Ibrahimi, Abdelhamid Znouda, Khaoula Abrougui, and Chehaibi Sayed

Simulation of Desiccation Cracking in Clayey Soil Using FEM-MPM

Coupling Method .

Jihen Feki, Houcem Trabelsi, and Sami Montassar

Elevated Temperature Affects Biochemical Responses and Oil

Quality in Olive Trees (Olea europaea L., cv Chetoui)

Yemine Ben Rouina, Mohamed Zouari, Nacim Zouari, Béchir Ben Rouina, and Mohamed Bouaziz

Drought Disturbance from Climate Change: Response of Cork Oak (Quercus Suber L.) Forests in North Africa (Tunisia) . . . . . . . . . . . . .

Issam Touhami, Hassane Moutahir, Juan Bellot, Touhami Rzigui, Hamdi Aouinti, Ali Khorchani, Mohamed Tahar Elaieb,

Abdelhamid Khaldi, and Zouheir Nasr

Change Detection Analysis of Vegetation Cover in the Middle Modder River Catchment (South Africa): Implications for Climate Variability 1003

Saheed Oke and Silent Ruzvidzo

Novel Aspects for Accounting and Monitoring Carbon Sequestration of Tree Crops in the Mediterranean; Environmental and Economic Benefits.

Kostas Bithas, Antonios Kolimenakis, and Angelos Mimis

Climate Change Adaptation and Resilience for Tunisian Farmers in Semi-arid Regions

Jamel Ben Nasr, Hatem Chaar, and Fadoua Bouchiba 
Non-use Value of Forest Ecosystem Services in Russia

Ekaterina $\mathrm{Li}$

Impact of Weather Parameters on Abundance of Liriomyza Cicerina (Agromyzidae) in the Northwest of Tunisia

Abir Soltani, Moez Amri, Antonio Carapelli, and Jouda Mediouni Ben Jemâa

The Amphistegina Invasion in the Monastir Bay, Tunisia

Mohamed Damak, Manel Ben Ismail, Rania Fourati, and Monem Kallel

Population Structure and Body Size of the Sahara Blue-Eyed Pond Turtle Mauremys leprosa saharica, from an Isolated Pond in Southern Morocco

Soumia Loulida, Mohammed Znari, Mohamed Naimi, and Safaa Bendami

Spatio-Temporal Structure of Rotifers Assemblages in a Lacustrine Ecosystem, Northern Algeria, a STATICO Analysis

Somia Hamil, Siham Arab, Ismahane Adaouri, Ikram Nasrouche, Amin Chaffai, Mounia Baha, and Abdeslem Arab

Abrupt and Sustained Acidification in Southern Tethyan Margin

During the Paleocene-Eocene Thermal Maximum: Impacts

on Foraminifera

Noura Kotti, Besma Mardassi, Ignacio Arenillas,

and Jamel Abdennaceur Ouali

Ecosystem Disturbance Records During the Uppermost

Maastrichtian-Lower Danian in Southern Tethyan Realms

(Gafsa Basin, Tamerza Area, Tunisia)

Salma Jmal, Noura Kotti, and Besma Mardassi

Implementation of the Climate Agreement in the Russian Oil

and Gas Sector .

Elena Mazlova, Tatiana Smirnova, Olga Kulikova,

and Yana Blinovskaya

Role of Environmental Variables on the Distribution of the Burmese Python in Florida 1063

Zella A. Conyers and Shouraseni Sen Roy

Natural Resources, Agriculture and the Environment: Agricultural Activities and Resources: Land Use, Impacts, Yield and Sustainibility

Humic Substances for Agricultural Applications: Properties and Challenges

Maris Klavins, Arturs Viksna, Maris Bertins, Janis Krumins, and Karina Upska 
Agricultural and Forest Land Use Changes in Poland Within 2003-2017

Agnieszka Pęska-Siwik

Assessment of the Sensitivity of Some Fusarium Root Rot Agents

to 6-Demethyl Mevinolin, a Putative Biosensitizer

Maxim Kartashov, Tatyana Pasechnik, Natalia Statsyuk,

Larisa Shcherbakova, and Vitaly Dzhavakhiya

Evolution of Nitrogen and Phosphorus in Tunisian Agricultural Soil

Under Controlled Conditions

Manel Allani, Hatem Ibrahim, and Abdessatar Hatira

Olive Mill Wastes in the Mediterranean: An Initial Assessment

of Organic Matter and Nutrients of Agricultural Value.

Evan Marks, Hanene Akrout, Vasiliki Kinigopoulou,

Charalampos Doulgeris, Salah Jellali, Carlos Rad, Paula Sánchez Zulueta,

Evangelos Tziritis, Leila El-Bassi, and Mejdi Jeguirim

Pollinator Impact on the Sterolic and the Triterpenic Dialcohol

Composition of Virgin Olive Oils (VOOs) from Southern Tunisia

Autochthonous Varieties.

Imen Oueslati, Hédia Manai-Djebali, Fawzia Mahjoub Haddeda,

Jacinto Sánchez-Casasc, and Xavier Fernandez

Importance of Phytosterols in the Classification of Tunisian Olive

Cultivars: Discrimination Between Varieties, Hybrids

and Oleasters

Hédia Manai-Djebali, Imen Oueslati, Béchir Baccouri, Zina Harzalli,

Manuel A. Martínez-Cañas, and Jacinto Sánchez-Casas

Behavior of the Chemical Composition of the Refined, Blended, and Extra Virgin Olive Oils During the Heating Process . . . . . . . . . . Imen Oueslati and Hédia Manai-Djebali

Olive Mill Solid Wastes: From Wastes to Biofertilizer

Lobna Bargougui, Mohamed Chaieb, and Ali Mekki

Supporting the Value Chain of Extra Virgin Olive Oil:

About the Reuse for Nutritional Purposes of Wet Olive Pomace

Giuseppe Russo, Simona Proietti, Stefano Moscatello, Marco Lauteri, and Andrea Pisanelli

Long-Term Olive Mill Wastewater Applications on Various Crops

Can Improve Productivity

Salwa Magdich, Béchir Ben Rouina, and Emna Ammar 
Socioecological Insights on the Sustainability of the Sweet Cherry Production Chain Within the Frame of a Lebanese Small Farming

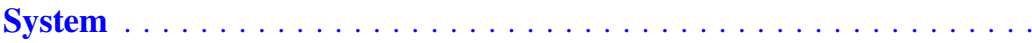

Giuseppe Russo, Stephanie A. Rahme, Fabio Ammar, Carlo Simonetti, and Marco Lauteri

Feasibility of Crop Production Using Greenhouse Fed by Desalination: A Review (MENA Regions)

Hassan Awaad, Abdelazim Negm, Hassan Fath, and Akbar Javadi

Effects of Regulated Deficit Irrigation (RDI) Applied at Different Growth Stages of Greenhouse Tomato on Yield and Fruit

Quality .

Amal Ghannem, Imed Ben Aissa, and Rajouene Majdoub

Tomato Growth Promotion Induced by Meyerozyma Guilliermondii Strain INAT (KU710283) in Controlled Conditions

Zayneb Kthiri, Maissa Ben Jabeur, and Walid Hamada

Durum Wheat (Triticum Durum) Sprouts Hygienic Quality at Different Temperature and the Role of Zinc on Improving

Microbial Properties

Sarra Jribi, Helga Molnàr, Otilia Tamara Antal, Nóra Adànyi,

Oussema Kheriji, Zoltan Naàr, and Hajer Debbabi

The Contribution of the Costs of Agricultural Inputs (to) Wheat

Hayat Lionboui, Tarik Benabdelouahab, Fouad Elame,

Abdelghani Boudhar, Adil Salhi, and Rachid Hadria

Quinoa Rehamna Project: High-Yielding Quinoa Cultivars

Introduction

Abdelaziz Hirich, Redouane Choukr-Allah, Mohamed El Gharouss,

Sifeddine Rafik, Juan Pablo Rodriguez Calle, Manal Mhada,

Khalil El Mejahed, Fatima Azaykou, and Kaouatr Filali

Quinoa Value Chain and Marketing Assessment in Morocco.

Abdelaziz Hirich, Meriem Chaoui, Yassin Assabban, Salima Jazi,

Redouane Choukr-Allah, Mohamed El Gharouss, Sifeddine Rafik, and Manal Mhada

Tunisian Durum Wheat Varieties: Influence of Geographical

Origin .

Hédia Manai-Djebali, Béchir Baccouri, Imen Oueslati, Zina Harzalli, and Abdelwahed Ghorbel 
Integrated Soil Fertility Management to Address Food Security and Enhance Forest Ecosystems Sustainability in "Trois Rivières" Forest Reserves (Benin, West Africa) . . . . . . . . . . . . . .

Romaric S. Lokossou, Gaston S. Akouèhou, Irénikatché P. B. Akponikpè, Romuald Davakan, Romain Glele Kakai, and Jean Ganglo

The Effect of Phosphorus Fertilization on Pepper Growth and Production Under Saline Conditions .

Sara Attaoui, Mohammed Oulahraoui, Redouane Choukr-Allah, Mohamed Fallah, and Khalid Azim

MultispeQ for Tracing Biostimulants Effect on Growth Promoting and Water Stress Tolerance in Wheat

Maissa Ben-Jabeur, Adrian Gracia Romero, Ruben Vicente, Zayneb Kthiri, Shawn Carlisle Kefauver, Maria Dolores Serret, Jose Luis Araus Ortega, and Walid Hamada

The Effect of Irrigation Water's Salinity on a Wheat Culture in the Presence of the Organic Matter

Affaf Masmoudi and Ali Masmoudi

How Peri-Urban Agriculture Can Contribute to the Sustainable Development of a Midsized City? The Case of Sahline (Tunisia)

Rawnek Slama, Christophe-Toussaint Soulard, and Hichem Rejeb

Monetary Evaluation as a Decision Support Tool for Environmental Assessment of Forest Natural Habitats

Ivo Machar and Vilem Pechanec

Agriculture and Land Stewardship: Can It Help Move from an Uncertain Present to a Sustainable Future .

Katherine Ann Spanos

Natural Resources, Agriculture and the Environment: Soil Impacts and Environment

Soil Organic Matter Rate Inside the Jessours Soil in the Matmata Mountainous Region . . . . . . . . . . . . . . . . . . . . . . . . . . . . . . . 1237

Habib Lamourou, Nissaf Karbout, Zied Zriba, and Mohamed Moussa

Sandstone Soils of the Cedar Forests of the Aures (Algeria):

Characteristics, Water Reserve, and Incidence on the Hydric

Balance Assessment

Saliha Halitim and Amor Halitim

Land Degradation Assessment in the Dry Areas of Tunisia Case Study: Wadi Koutine Watershed

Mongi Ben Zaied, Mohamed Ouessar, Messaoud Guied, and Hedi Kerdi 
Heavy Metal Contamination Degree of Soils Surrounding the Rehabilitated Dump of Oued Smar, Algeria.

Nadjib Benosmane

Macro- and Micro-Nutrients Composition and Concentration in Al-Uja Soil Under a Date Palm Plantation, Palestine .

Asmaa Abu-Hammad, Amer Marei, and Rezeq Salimia

Effect of Manure and Differing Sand Amendments on the Soil

Chemical Properties of the Oases in Tunisia

Nissaf Karbout, Roland Bol, Rawan Mlih, Mohamed Moussa,

Habib Lamoro, Nadhem brahim, and Habib Bousnina

Modelling of the Soil Organic Fraction in a Limestone Deposit

Within a Mediterranean Environment .

Hatem Ibrahim, Nadhem Brahim, Didier Blavet, and Marc Pansu

Measuring the Engineering Properties of Landfill Leachate-

Contaminated Soil

Safia Khodary, Hassan Fath, Abdelazim Negm, and Ahmed Tawfik

Intensity of Chemical Weathering Over Three Meta-igneous Rocks:

Importance for Trace Metals Enrichment in Soil Profiles

Saheed Oke

PGPR Traits of Rhizospheric Nocardiopsis Strains Isolated

from Algerian Soils

Lamia Aouar, Inas Boukelloul, and Abderrahmane Benadjila

Control and Regeneration of Degraded Protected Forest Area

Using Microbially Induced Calcite Precipitation: A Review

Amir Tophel and G. V. Ramana

Natural Resources, Agriculture and the Environment: Biodiversity and Ecological Systems: Impacts and Remediation

Assessing the Conservation Viability of the Easternmost Wetland of the Mancha Húmeda Biosphere Reserve (Spain)

África de la Hera-Portillo, Marco Filipe Callaú Lópes,

Julio López-Gutiérrez, and Teresa Orozco-Cuenca

Echophysiology of Camel Ovarian Functioning at Algerian Extreme Arid Conditions

Djallel Eddine Gherissi, Zoubir Bouzebda, Farida Bouzebda-Afri,

Faycel Chacha, Ramzi Lamraoui, Amina Gherissi, and Abd Latif Miloudi

Linking Livestock Production and Wild Biodiversity: Contribution of Pastoral Production Systems to the Habitat of Bird Priority

Conservation Species

Oscar Blumetto and Andrés Castagna 
Insights into Nematode Biocontrol Potential Through Biological and Proteomics Analysis of the Fungus Trichoderma viride

Lobna Hajji-Hedfi, Emna Ben Khaled, Suzana Cobacho Arcos,

Lee Robertson, Sergio Ciordia, María Rosa Gonzalez,

Najet Horrigue-Raouani, and Alfonso Navas

Simulation of Phytomass Dynamics of Plant Communities Based on Artificial Neural Networks and NDVI

Vladimir Mikhailov, Marija Ponomarenko, and Vladislav Sobolevsky

Padina pavonica and Jania rubens Associated Bacteria: Biodiversity and Antibacterial Potential.

Amel Ismail, Leila Ktari, Mehboob Ahmed, Radhia Mraouna,

Imen Hmani, Abdellatif Boudabous, and Monia Elbour

Epidemiology of Pesticide Poisoning Among Children

in Morocco .

Zakaria Abidli, Sara Jadda, Hinde Hami, Donia Kharbouch, Latifa Amiar,

Abdelrhani Mokhtari, Naima Rhalem, and Rachida Soulaymani-Bencheikh

Impact of Dietary Fibers on the Biochemical Markers of Bone

Remodeling in Hemodialyzed Postmenopausal Women (Algeria) . . . . .

Fatima Mehenni, Boumediene Meddah, and Aicha Tir Touil Meddah

First Report on the Copro-parasitology of Striped Hyena, African

Golden Wolf and Red Fox in Chrea National Park, (Algeria) . . . . . . .

Djamel Bendjoudi, Faiza Marniche, Lilia Takdjout, and Manuel Epalanga

The Earthworm Fauna of Chréa National Park (Algeria)

Lahcen Zerrouki, Warda Essarhane, Somia Hamil, and Mounia Baha

The Distribution of Soil Fauna in the Forest of Theniet El Had

Mohamed Nadjib Benzohra, Soumia Hamil, and Mounia Baha

MF3 Protein Encapsulation in Biodegradable Poly-3-Hydroxybutyrate

Improves Its Protective Action Against a Major Wheat Pathogen

Parastagonospora Nodorum . . . . . . . . . . . . . . . . . . . . . .

Tatiana Voinova, Maxim Kartashov, Larisa Shcherbakova,

Natalia Statsyuk, and Vitaly Dzhavakhiya

Efficiency of Alkaloids Crude Extract of Cinnamomum Zeylanicum as Corrosion Inhibitor of Mild Steel in Sulfuric Acid Solution .

Souad Djellali, Hana Ferkous, Rachid Sahraoui, and Sara Meharga

Chemical Analysis and Metal Chelating Power of Crude Extracts

from Three Medicinal Plants: Cistus creticus, Cinnamomum

zeylanicum, and Rosmarinus officinalis

Souad Djellali and Rachid Sahraoui 
Comparing Chemical Composition and Phenolic Compounds of Some Herbals as Potential Feed Additives in Ruminant

Nutrition

Samir Medjekal, Mouloud Ghadbane, Souhil Boufennara,

Laid Benderradji, Raul Bodas, Hacène Bousseboua, and Secundino López

Valorization of Agave Americana Fibers in the Preparation of Activated Carbon and Removal of Dyes from Aqueous

Solutions

Taher Selmi, Ghizlane Enaime, Aïda Kesraoui, Abdelaziz Baçaoui, and Mongi Seffen

In Vitro Multiple Solution Extracts from Leaves of Artemisia judaica

L. Var. Sahariensis (L. Chevall.) Collected from the Algerian Sahara and Its Antimicrobial Activities Against Pathogenic

Microorganisms

Laid Benderradji, Mouloud Ghadbane, Noura Messaoudi, and Lydia Elhadef El Okki

Pomegranate Peel Powder as a Green Eco-Friendly Corrosion

Inhibitor for Steel rebar's Embedded in Cement Paste

Imen Assadi, Marwa Trimeche, Walid Elfalleh, Aymen Amine Assadi,

Ali Ferchichi, and Naceur Etteyeb

Controlling the Porosity and Strength of Liquefied Spruce Tree

Sawdust Based Carbon Foams via Changing Surfactant Amoun

Adife Seyda Yargic and Nurgul Ozbay

What's Left of the Pear Tree After the Fire Blight Outbreak?

An Urgent Need for Germplasm Preservation

Mehdi Trad

Some Biochemical Changes in the Lichen Evernia prunastri Exposed

to Atmospheric Pollutants

Gordana Bogdanović-Dušanović, Nedeljko Manojlović,

Radmila Trajković, Dragoslav Pejčinović, and Jovica Tomović

Situation and Environmental Impacts of Phytosanitary Treatments for Greenhouse Vegetable Crops in the Region of Biskra

(ALGERIA)

Toufik Aidat and Salah Eddine Benziouche

Mediterranean Seaweeds as Source of Bioactive Compounds:

Case Study of Some Red Algae (Rhodophyta) from North Coast

of Tunisia

Imen Hmani, Leila Ktari, Amel Ismail, Cheima M'dallel,

and Monia El Bour 
Effect of Incorporating Natural Sweeteners in Jams on Appetite,

Palatability and Consumers' Acceptance

May Ouhaibi, Sarra Jribi, and Hajer Debbabi

Disperse Blue 1 Removal Using Three Formulations of Cactus

Extracts: A Comparative Study with a Chemical Flocculant

Bouthaina Othmani and Moncef Khadhraoui

Activated Carbon from Prickly Pear Seeds: Optimization of Preparation Conditions and Cadmium Removal Using

Experimental Design Approach

Rimene Dhahri, Asma Bouzidi, and Younes Moussaoui

Synthesis and Application of Algerian Natural Kaolin Modified 13X

Zeolite for the Treatment of Real Textile Effluent

Asma Dhiffalah, Fatima Zohra EL Berrichi, Nor el Houda Fardjaoui,

Ibtissem Slatni, Ammar Maoui, Brahim Gasmi, Joelle Duplay, and Malika Ghazi

2-(2-Methoxybenzylidene) Hydrazine-1-Carbothioamide as Efficient Organic Inhibitor for Mild Steel in Hydrochloric Acid Solution

Hana Ferkous, Souad Djellali, Rachid Sahraoui, Hamza Behloul, Khaoula Saoud, and Alaaddin Çukurovali

Thermodynamic and Electrochemical Studies of Corrosion Inhibition of Carbon Steel by Rosmarinus Officinalis Extract in Acid Medium

Amina Belakhdar, Hana Ferkous, Souad Djellali, Hana Lahbib, and Yasser Ben Amor

$\mathrm{TiO}_{2}$ Supported on Clay-Cement Hybrid Materials and Wood Fibers as Photocatalyst for Phenol Photodegradation

Latifa Morjène, Minoo Tasbihi, Michael Schwarze, Fadhel Aloulou, and Mongi Seffen

Chemical Composition and Activity of Lavandula Angustifolia Essential Oil Against Stored-Product Pest Rhyzopertha Dominica (F.) (Coleoptera: Bostrichidae): Fumigant Toxicity, Food Intake and Digestive Enzymes .

Samir Tine, Nardjess Sayada, Fouzia Tine-Djebbar, and Noureddine Soltani

Efficient Conversion of Rapeseed Cake into Bio-Alcohol

Through Pyrolysis

Elif Yaman, Nurgül Özbay, Sinan Temel, and Fatma Özge Gökmen

Inspection of Trees Using Infrared Thermography

Rui Pitarma and João Crisóstomo 
Pollution and Physiological Changes in the Leaves of Apricot

Plants

Mohamed Zouari, Nada Elloumi, Monem Kallel, and Béchir Ben Rouina

Infrared Thermography Applied to Trees: Short Review

Daniele Vidal and Rui Pitarma

Natural Resources, Agriculture and the Environment:

Environmental Sustainable Water Systems and Impacts

Survey of Seawater in the Coastal Area of the Black Sea in Front

of Cape Galata (Bulgaria)

Slava Dineva

Varna Bay (Bulgaria): Research Based on Water-Related

Challenges

Slava Dineva

Water Balance Estimation in Semiarid Mediterranean Watersheds

Using SWAT Model

Yassine Bouslihim, Aicha Rochdi, and Namira El Amrani Pazza

Participatory Management of Irrigation Water in Morocco: Lessons from a Case Study in Souss-Massa Region.

El Houssaine Erraoui and Hanane Azemzi

Application of CCME-WQI and Trend Analysis for Water Quality Assessment of the largest Dam in Algeria

Ahmed Amin Soltani, Abdelmalek Bermad, Hamouda Boutaghane, and Mahmoud Hasbaia

Assessment of the Surface Water Quality of Kebir-Rhumel Catchment Area Through Physico-Chemical and Biological

Analysis

Imane Saal, Djaouida Bouchelouche, Mouna Hafiane, Ceria Hamache, and Abdeslem Arab

The Trophic Status of the Bakhadda Dam Lake Using Physicochemical Analysis and Trophic Index .

Ghiles Smaoune, Djaouida Bouchelouche, Nassima Doukhandji, and Abdeslem Arab

Multivariate Statistical Techniques to Evaluate Spatial Variations in Water Quality Case Study: West-Central Algeria

Ismahane Adaouri, Somia Hamil, Siham Arab, Djaouida Bouchelouche, Amin Chaffai, Ikram Nasrouche, Safia Akli-Bidi, and Abdeslem Arab 
Effect of Magnetic Treatment of Irrigation Water on Spinach Matador (Spinacia Oleracea L) Growth and Soil Characteristics .

Hsan Youssef Mehdaoui, Nadia Castanheira, Manuela Roldão Oliveira, Salma Mseddi, Maria da Conceiçao Goncalves, and Monem Kallel

Qualitative Appreciation of Water Resources in a Preserved Environment Under Anthropic Threat

Badreddine Saadali, El Fadel Derradji, Feyrouz Hafid, Yasmina Bouroubi, Nadjib Haied, and Mahrez Boulabeiz

Origin of High Fluorine Contents in Drinking Water in the Province Capital of Isparta, SW Turkey

Nevzat Özgür

Wadi Wastewater Flowing Effects on the Spring Water Quality of Sarida Catchment-West Bank

Waseem Ahmad and Marwan Ghanem

Contaminants of Emerging Concern in (Waste) Water: Evaluating the Knowledge Status Among Decision-Makers and Stakeholders

in Tunisia

Olfa Mahjoub, Loubna Benyahya, Despo Fatta-Kassinos, Serge Chiron, Elke Fries, and Sarantuyaa Zandaryaa

Urban Wastewater Treatment by Infiltration Percolation:

Comparative Study of the Purification Performance of Sand Filter

Through a Simple and Double Column . . . . . . . . . . . . . . . . . . . . 1609

Feryel Hajjaji and Saifeddine Eturki

Valorization of Oilfield Produced Water on the Recovery

of Valuable Salt

Hassan ElGharbi, Mohamed Triki, Ridha Amdouni,

Subrata Borgohain Gogoi, and Monem Kallel

Hydrogeochemical Investigation of the Apennine Carbonate Springs

by Factor Analysis .

Francesco Rufino, Gianluigi Busico, Emilio Cuoco, Matteo De Santis, and Dario Tedesco

Hydrochemical Evolution of Groundwater Within the Amansie and Adansi Districts of the Ashanti Region (Ghana)

Collins Tay, Michael Dorleku, and Samuel Koranteng

Subsurface Characterization Using Geoelectrical Sounding in Canaan-City Estate, Ota SW Nigeria: Implications

for Groundwater Exploration.

Kehinde D. Oyeyemi, Ahzegbobor P. Aizebeokhai, and BabaMayowa A. Bayo-Solarin 
Characterization of the Fissured Layer Properties in Crystalline

Bedrock Aquifers of Gbêkê Region in the Central Area

of Côte D'Ivoire .

Aristide Gountôh Douagui, Innocent Kouassi Kouamé,

Boris Kouassi Kouamé, and Issiaka Savané

Impact of Recharging Structures on the Piezometry

of the Grombalia Ground Water

Rym Mhamdi and Mohamed Mechergui

The Hidden Information in Observations of Groundwater Well

Records in a Complex Multilayer Aquifer

África de la Hera-Portillo, Eduardo Peña-Corriá, Rodrigo García-Lorenz,

Julio López-Gutiérrez, Ester Rodríguez-Jiménez, Rocío Martín-Gamo,

Carmen Macías, Cristian Cobaleda, Fortunato García-López,

and Teresa Orozco-Cuenca

Water Quality Assessment of the Shallow and Deep Aquifers

of Hajeb Layoun-Jelma Basin (Central Tunisia)

1663

Soumaya Aouiti, Fadoua Hamzaoui-Azaza, Mounira Zammouri,

Monji Hamdi, and Fulvio Celico

Artificial Neural Networks: Intelligent Approach to Simulate

Groundwater Level Pattern

Malek Derbela and Issam Nouiri

Analytical Hydrological Model for the Planning and Design of Low-Impact Development Practices

Sonia Hassini and Yiping Guo

Seepage Velocity of Different Groundwater Aquifers in Halabja

Saidsadiq Basin-NE of Iraq

Twana Abdullah, Salahalddin Saeed Ali, Nadhir Al-Ansari, and Sven Knutsson

Seepage Velocity Mapping Using ArcMap/GIS Software .

Qais Al-Madhlom, Nadhir Al-Ansari, Hussain Musa Hussain, and Jan Laue

Water Management and Retention Opportunities Along the Hungarian Section of the Drava River

Ali Salem, József Dezső, Mustafa El-Rawy, and Dénes Lóczy

Integrated Ensemble Weight of Evidence and Logistic Regression for Potential Groundwater Mapping: An Application to the Northern Piedmont of High Atlas Mountains (Morocco)

Hassane Rahali, Siham Elaryf, Hicham Amar, and Bouchra Zellou 
Smart Technologies for Environmentally Friendly Energy Production

Torrefaction of Wheat Straw and Sunflower Shells Biomasses

as Low-Cost Materials for Energy Co-Generation

H. Demey, T. Melkior, A. Chatroux, M. Grateau, P. Pons de Vincent,

S. Thiery, H. Miller, and M. Marchand

Free-Methane: Producing Fuel from Waste $\mathrm{CO}_{2}$ Using

Renewable Energies

Stefano Falcinelli

Optimization of Simultaneous Production of Bio-Hydrogen

and Bio-Methane from Food Wastes

Mouna Yahya, Christiane Herrmann, Samir Ismaili, Carsten Jost, and Achraf Ghorbal

Characterization of the Inclusion of Polymer Membrane

for Application as Electrolyte in Direct Methanol Fuel

Cell System

Kaoutar Aghmih, Imane Touarssi, Said Gmouh, Miloudi Hlaïbi, and Sanaa Majid

Evaluation of the Methanogenic Potential of Tunisian Vegetables and Fruit Wastes: Biogas Production and Characterizations

Samira Abidi, Gmar BenSidhom, Sana Amdouni,

Mohamed Hechmi Aissaoui, and Aïda Ben Hassen Trabelsi

Study of Thermal Stability and Characterization of the Biodiesel from Waste Frying Oil

Mariem Harabi, Ana Inés Fernández, and Mohamed Bouaziz

Deposition of Cd-Doped ZnO Thin Films as Transparent Electrode

for Solar Cell Applications .

Fatma Özge Gökmen, Sinan Temel, and Elif Yaman

Utilization of Exhausted Oxygen from Nitrogen Plant to Improve

Sulfur Recovery Unit and Reduce Emissions-Case Study

Wahid Alzmzam and Walid Alfaghi

Remote Sensing and GIS for Environmental Monitoring and Management: Spatial Modelling and Tools in Environmental Monitroing and Assessment

Assessment of Drought Impact on Surface Water in the Mockes

Dam of the Free State, South Africa, Using Remote Sensing

Techniques

Saheed Oke and Silent Ruzvidzo 
GIS-Based Model for Vulnerability and Seawater Intrusion Risk Assessment by Combined Chemical Indicators and GALDIT Tools:

The Case of a Coastal Aquifer in Monastir, Tunisia

Rihem Mejdoub El Fehri, Mahmoud Dlala, and Lamia Kouzana

The Ground Water Potential of a Key Junction Zone Between

the Afar Rift Floor and Western Afar Margin of Ethiopia

Nicola Perilli, Simone Gorelli, and Abeer Albalawneh

Improvement of GIS-Based DRASTIC Model Using Step-Wise

Weight Assessment Ratio Analysis (SWARA) and Two New Hybrid

Frameworks (Iran)

Maryam Torkashvand, Aminreza Neshat, Saman Javadi,

and Hossein Yousefi

Integration of ELECTRE III and AHP-Multicriteria Decision

Analysis for Identification of Suitable Areas for Artificial Recharge

with Reclaimed Water

Marwa Mahmoudi, Abdelwaheb Aydi, Nadhem Brahim, Wissal Issaoui, and Najet Shimi

Ecologic-Economic Zoning of a Small Water Catchment Basin

in Vacaria, Southern Brazil

Vania Elisabete Schneider, Geise Macedo dos Santos,

Sofia Helena Zanella Carra, Denise Peresin, Taison Anderson Bortolin, and Gisele Cemin

Geological Field Mapping and Heavy Metals Assessment in Soils

of Abandoned Mine Site in Dorowa, Northcentral

Nigeria . . . . . . . . . . . . . . . . . . . . . . . . . . . . . . . . . . 1805

Kehinde D. Oyeyemi, Joyce Abuka-Joshua, Ahzegbobor P. Aizebeokhai,

Osagie A. Ekhaguere, Opeyemi Joshua, and David O. Nduka

Combining GIS Applications and Analytic Hierarchy Process

Method for Landfill Siting in Sulaimaniyah, Iraq

Karwan Alkaradaghi, Salahalddin Saeed Ali, Nadhir Al-Ansari,

and Jan Laue

Remote Sensing and GIS for Environmental Monitoring

and Management: Earth Observation for Land Use

and Natural Ressources Assessment

Urban Morphology and Anthropogenic Heat Effect on Land Surface

Temperature: Bab Ezzouar (Algiers) Case Study

Assia Fernini-Haffif and Ewa Berezowska-Azzag 
Assessing Land Degradation Neutrality (LDN) in Southeastern Tunisia Based on Earth Observation Data and Open Source Applications

Olfa Terwayet Bayouli, Bouajila Essifi, and Mohamed Ouessar

Production of a Land Cover/Land Use (LC/LU) Map of Izmir Metropolitan City by Using High-Resolution Images .

Elif Sertel, Raziye Hale Topaloğlu, Kübra Bahși, Beril Varol, and Nebiye Musaoğlu

The Use of Satellite Image and GIS to Monitor Deforestation of Akure Forest Reserve and Its Environs, Ondo State, Nigeria

Michael Oyinloye and Fidelis Ado

Assessment of Vegetation Cover Using Normalized Difference Vegetation Index Based on Satellite Images: Case Study from Ajloun in Northern Jordan

Anna Igorevna Kurbatova, Hani Abu-Qdais,

Elizaveta Andreevna Grigorets, and Polina Viktorovna Kozhevnikova

An Internet of Things and Wireless Sensor Networks Hybrid Architecture for Precision Agriculture Monitoring. 1863 Gonçalo Marques and Rui Pitarma

Trend Analysis Using Discrete Wavelet Transform (DWT) for Non-stationary NDVI Time Series in Tunisia . . . . . . . . . . . . . . . . . 1869 Manel Rhif, Ali Ben Abbes, Imed Riadh Farah, and Beatriz Martínez

Remote Sensing and Integrated Geophysical Investigations of Unstable Sections of Ibadan-Iwo-Osogbo Highway, Southwestern Nigeria 1875 Omowumi Ademila, Abel Idowu Olayinka, and Michael Adeyinka Oladunjoye

Evolution of Aerosol Radiative Forcing in Beijing (China) 1883

Rajae Meziane, Mohammed Diouri, Ibtissam Marsli, and Azhare El Khabbouti

Map of the Global Pollution of the Algiers Region Established by the IAP Method (Index of Atmospheric Purity)

Henia Saib, Mohamed Toumi, and Mohammed Rahali

Evaluation of TRMM 3B42 V7 Rainfall Product in Morocco

Rachid Hadria, Adil Salhi, Tarik Benabdelouahab, Loubna Elmansouri, Hayat Lionboui, Hamza Ouatiki, Youssef Lebrini, Abdelaziz Htitiou, and Rida Khellouk 
Pilot Activities in Creating Soil Maps from Satellite Data-Struma

River Valley Case Study

Hristo Nikolov and Toma Shishkov

Environmental Impacts of Natural Hazards and Environmental Risk

Assessment: Water Quality Impacts on Environmental Ecosystems

The Impact of Environmental Factors on the Diaphanosoma sp

Distribution in Ghrib Lake (Northern Algeria)

Somia Hamil, Siham Arab, Warda Esserhane, Mounia Baha, and Abdeslem Arab

Water Quality Shapes Freshwater Macroinvertebrate Communities in Northern Tunisia .

Noura Slimani, David Sánchez-Fernández, Eric Guilbert,

Moncef Boumaïza, and Jean Thioulouse

Surface Water Quality Assessment of Lacustrine Ecosystem Case

Study of Boukourdane Dam, Algeria

Siham Arab, Somia Hamil, Ismahane Adaouri, Amin Chaffai,

Ikram Nasrouche, and Abdeslam Arab

Application of Multivariate Statistical Analysis in the Assessment of Surface Water Quality in the Hydrographic Network of Mazafran

Wadi, Algeria

Djaouida Bouchelouche, Hind Sefiane, Imane Saal, Mouna Hafiane, and Abdeslem Arab

Assessment of Drought Characteristics, and Its Impacts

on Vegetation and Wheat Yield in Tunisia.

Nada Ben Mhenni, Masato Shinoda, and Banzragch Nandintsetseg

Study of Water Quality Using Multivariate Analysis in Coastal

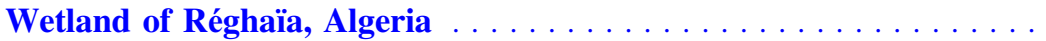

Djaouida Bouchelouche, Imane Saal, Mouna Hafiane, and Abdeslem Arab

Environmental Impacts of Natural Hazards and Environmental Risk Assessment: Environmental Characterisation and Analysis on Hydrological Hazards Systems

Risk Analysis of the Maximum Daily Precipitation in the Southwest of the Iberian Peninsula Over the Period 1861-2016

Leoncio García-Barrón, Mónica Aguilar-Alba, Julia Morales, and Arturo Sousa

Evaluation of Drought Severity Changes in Iran Using Hurst

Exponent and Standardized Precipitation Index

Zahra Noorisameleh, William A. Gough, and M. Monirul Qader Mirza 
Investigating Extreme Sea Levels from the Meteorologically Induced Modulation Along the English Channel Coasts 1961 Imen Turki and Yasser Hamdi

Study of the Risks of the Tsunami at Tunisian Coasts 1967

Lassaad Sahli, Kanfoudi Hatem, Aicha Abbassi, and Ridha Zgolli

Sea Level Characteristics and Return Periods at Port Said Harbour, Egypt

Tarek Mohamed El-Geziry

Modelling Flood Risk in Rural Areas: The Case of the Arbaa Taourirt Centre (Morocco) 1981 Adil Salhi, Abdelmonaim Okacha, Sara Benabdelouahab, Mahjoub Himi, Tarik Benabdelouahab, and Albert Casas Ponsati

Probabilistic Multi-hazard Risk Assessment-Development of an Aggregation Model Based on the Algebra of Events

Yasser Hamdi, Amine Ben Daoued, Nassima Mouhous-Voyneau, and Philippe Sergent

Assessment of Land Use Vulnerability to Flood Disaster Management; and Control in Ikirun, Osun State, Nigeria . 1997

Martin Binde Gasu and Ayokunle Olaide Odusola

Coastal Flooding Risk Assessment Through Artificial

Intelligence 2005

Claudio Iuppa, Luca Cavallaro, Claudia Giarrusso,

Rosaria Ester Musumeci, and Giovanni Savasta

Development of a Probabilistic Multi-flood Hazard Approach Considering Uncertainties and Climate Change-Application to the Coastal Flooding of the Havre (France) . . . . . . . . . . . . . . . 2011 Amine Ben Daoued, Nassima Mouhous-Voyneau, Yasser Hamdi, and Philippe Sergent

Environmental Impacts of Natural Hazards and Environmental Risk Assessment: Environmental Risk Assessment

Soil Erosion Assessment and Farmers' Perception in South Mediterranean Basins: A Moroccan Case Study . . . . . . . . . . . . . . . . 2019 Adil Salhi, Tarik Benabdelouahab, Yassin El Hasnaoui, Mhamed El Moussaoui, Abdelkarim El Morabit, Mahjoub Himi, Sara Benabdelouahab, Albert Casas Ponsati, Rachid Hadria, and Javier Martin-Vide 
Trace Element Concentrations in Commercial Fish Collected from Coastal Area and Rivers of Bangladesh-Human Health Risk

Moumita Saha Bristy, Kishor Kumar Sarker, Mohammad Abdul Baki,

Shamshad Begum Quraishi, Mohammad Shahidur Rahman Khan, and Md Firoz Khan

The Exposure-Happenstance Concept Model: A Case Study Within the Foot Slopes of Mayon Volcano, Albay, Philippines. 2031 Ana Marie R. Abante

Wildfires and Socioeconomic Variables in Galicia, Spain: Panel Data Analysis

Jaime de Diego, Mercedes Fernández, and Antonio Rúa

Hazardous Materials Prediction Using an Artificial Neural Network and Meteorological FASDAS Data Assimilation . .

Hosni Snoun, Hatem Kanfoudi, Ghazi Bellakhal, and Jamel Chahed

Prediction of Earthquake-Induced Liquefaction State

in Embankment Dams Using Back-Propagation Neural

Network

Abdelatif Zeroual, Messaoud Djeddou, and Ali Fourar

Assessment of Static and Seismic Bearing Capacity Factors

of Shallow Strip Foundations Using the Discontinuity Layout

Optimization Procedure

Mohamed Khemissa and Imane Harzallah

Adding New Information Content to GNSS Measurements

by SAR Data Processing in Studying a Landslide

Mila Atanasova and Hristo Nikolov

An Environmental and Financial Risk Assessment Protocol

for the Investments in the Energy Sector .

Antonio Nesticò, Gianluigi De Mare, Shuquan He,

and Gabriella Maselli

Sustainable Management of Marine and Coastal Environments:

Characterization and Management of Marine and Costal

Environments

Water Pollution Monitoring Study for Protected Areas at Eastern

Mediterranean Sea, Turkey . . . . . . . . . . . . . . . . . . . . . . . . . . 2077

Nevzat Özgür

Microplastic (MP) Pollution in Sidi Youssef Harbor of the

Kerkennah Islands, Sfax (Tunisia) . . . . . . . . . . . . . . . . . . . . . 2083

Khawla Chouchene, Teresa Rocha-Santos, and Mohamed Ksibi 
Comparative Study of Various Treatment Processes of Crude Oil Associated Water Produced from the Upper Assam Basin (India) . . . 2089 TapanJyoti Gogoi, Subrata Borgohain Gogoi, Pranab Boral, and Monem Kallel

Characterization of Deep-Sea Sediment Microbial Communities from Different Mediterranean Sea Regions . . . . . . . . . . . . . . . . 2095 Monia EL Bour, Micha Rijkenberg, Aymen Saadi, Maria Virginia Martins, and Noureddine Zaaboub

Assessing the Efficacy of Dredged Sediments from Zarzis Harbor, Tunisia: Implication to Agriculture . . . . . . . . . . . . . . . . . 2103 Afef Zouch, Mohamed Elwachem, Olfa Hentati, and Mohamed Ksibi

Sedimentary Phosphorus Dynamics in the Mediterranean Rhône River Prodelta: Data-Modeling Approach

Fatima Ezzahra Ait Ballagh, Christophe Rabouille, Françoise Andrieux-Loyer, Karline Soetaert, Khalid Elkalay, and Karima Khalil

Characterization and Dynamics of the Pollutant Load Discharge Carried by the Mazafran River (N Algeria) on the Coastal

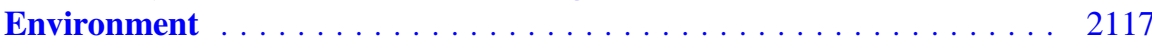

Zenati Billal, Inal Ahmed, Kourdali Sidali, Mesbaiah Fatma-Zohra, Meknachi Abdellah, and Bachouche Samir

Socioeconomic and Ecological Situation of Mogador Marine Protected Area in Morocco

Ghoufrane Derhy, Khalid Elkalay, Nezha Ait Taleb, Zainab Damsiri, and Karima Khalil

Moroccan Atlantic Marine Research State of the Art: A Review Analysis .

Khalid Elkalay, Hanane Rhomad, Zainab Damsiri, Hassan Essekhyr, Ghoufrane Derhy, and Karima Khalil

The Study of the Heart of A. Boyeri Caspia in Environmental Quality Assessment . 2135

Nailya Ibragimova, Saule Shalgimbayeva, Nikolay Popov, and Gaukhar Jumakhanova

Sustainable Management of Marine and Coastal Environments:

Tools in Marine and Costal Sustainable Development

Integration of Architecture and Landscape as Part of the Sustainable Development of the Coastline . 2143

Magdalena Czalczynska-Podolska and Wojciech Bal 
Comparison of Pixel-Based and Object-Oriented Classification

Methods for Extracting Built-Up Areas in Coastal Zone

Chayma Kefi, Amina Mabrouk, Nabila Halouani, and Haythem Ismail

Wetland Contracts: Voluntary-Based Agreements

for the Sustainable Governance of Mediterranean Protected

Wetlands

Giancarlo Gusmaroli, Giuseppe Dodaro, Ileana Schipani, Claudio Perin,

Franco Alberti, and Stefano Magaudda

Repository of Technical Documents for a Sustainable Management of Marine and Coastal Environments: The New Portal

www.coastalmapping.eu

Tullia Valeria Di Giacomo and F. Paolo DI Giacomo

Understanding the Source, Distribution, and Fate of Micro- and

Nanoplastics in Natural Water Bodies

Valter Castelvetro, Andrea Corti, Alessio Ceccarini, Jacopo La Nasa,

Tommaso Lomonaco, Antonella Manariti, Enrico Manco,

Francesca Modugno, and Virginia Vinciguerra

An Algorithm for Assessment of the Water Purification by Seaweeds:

An Application for a Black Sea Recreational Coastal Area .

Sergey Kovardakov, Nataliya Milchakova, and Vladimir Alexandrov

The Condition of the Red Alga Phyllophora crispa (Hudson) P.S.

Dixon and Proposals for MPA Optimization in Southwestern

Crimea, Black Sea

Vladimir Alexandrov and Nataliya Milchakova

Which Is a More Reliable Bioindicator-Mussels or Seagrass?

A Case Study of the Toxic Metal Pollution in the Seawater of Boka

Kotorska Bay, Adriatic Sea . . . . . . . . . . . . . . . . . . . 2185

Slavka Stankovic, Ana Perosevic, Lato Pezo, Stevan Blagojevic,

and Antonije Onjia

The Influence of Sea Surface Temperatures on Biodiversity of Gaeta

Gulf, Italy .

Matteo Gentilucci, Adriano Madonna, and Giulia Guerriero

Measures for the Protection and Sustainable Exploitation of Marine

Biological Resources in an Oligotrophic Fishing Ground

(Crete Island, Greece, E. Mediterranean).

Panayota Koulouri, Marianna Giannoulaki, Athanasios Machias, and Costas Dounas 
New Insight into Marine Biotechnology: Carrageenans Chemical Features and Acetylcholinesterase (AChE) Inhibition Activity of Two

Edible Seaweeds of the Genus Kappaphycus . . . . . . . . . . . . . . . . . 2203

Oladokun Sulaiman Olanrewaju, Giuseppina Tommonaro,

Giulia Guerriero, Chiara Fogliano, Carmine Iodice, Gennaro Velotto, and Annabella Tramice

\section{Sustainable Management of the Urban Environment}

An Economic Model to Assess the Long-Term Implications

for Investments Aimed at Urban Sustainability . . . . . . . . . . . . . . . 2211

Antonio Nesticò and Gabriella Maselli

Integration of Sustainable Risk-Based Land Management Approach

into Developing Countries, Libya as a Case Study . . . . . . . . . . . . . . 2217

Salahadein Ahmed Alzien and Rafig Azzam

Safety Maintenance: Reduction of Dioxins/Furans Levels After

Urban Landfill Upgrade (Armenia) . . . . . . . . . . . . . . . . . . . . . 2223

Anahit Aleksandryan and Artak Khachatryan

Impact of the Extension of Energy Infrastructure Elements

on the Landscape . . . . . . . . . . . . . . . . . . . . . . . . . . . . . 2227

Edward Preweda and Krzysztof Butryn

Integrating Plants and Trees in the Design of Urban Parks

in Marseille . . . . . . . . . . . . . . . . . . . . . . . . . 2233

Brice Dacheux-Auzière and Yves Petit-Berghem

Urban Morphology and Solar Gains in Cities with Warm

Mediterranean Climate: Comparison of Two Collective Residential

Complexes in Tunis, Tunisia . . . . . . . . . . . . . . . . . . . . . . . . 2241

Nour El Houda Jouini, Fakher Kharrat, and Safa Achour-Younsi

Development and Validation of a Grid to Evaluate Ecosystem

Services of Public Urban Green Spaces in Porto

(Portugal) .

Diogo Guedes Vidal, Cláudia Oliveira Fernandes,

Lilian Monteiro Ferrari Viterbo, Helena Vilaça, Nelson Barros, and Rui Leandro Maia

Numerical Study of Traffic Noise Dispersion Based on the Coupling Between First-Order Traffic Model and French Noise Prediction

Method . . . . . . . . . . . . . . . . . . . . . . . . . . 2253

Hana Mosbahi, Abdessalem Jbara, Emna Khamassi, and Khalifa Slimi 
Application of the Ultrasonic Sounding Method for Monitoring the Preservation of Stone Monuments

Evgenii Nesterov, Vera Egorova, Vladislav Shakhov, and Olga Frank-Kamenetskaya

Recycling Way of Sludge in Handcraft Pottery (Marrakesh, Morocco)

Rachida Bouachera, Mariam El Aoud, Rachida Kasimi,

Mounsif Ibnoussina, Yassine Taha, Hicham El Boudour El Idrissi, and Rachid Hakkou

Pyrolysis of Municipal Sewage Sludge within a circular economy vision: Production of sustainable Biofuels and Economic Biofertilizers .

Aïda Ben Hassen Trabelsi, Athar Friaa, Samira Abidi, Slim Naoui, and Faycel Jamaaoui

Sustainable Management of the Indoor and Built Environment

Evaluation of Display Materials in Shanghai Museum: Situation in the Past Three Years and Prospect of the Future

Development. . . . . . . . . . . . . . . . . . . . . . . . . . . . . . . . . . . 2281

Jingyi Shen and Yijia Shen

Camphor Wood Used as a Museum Storage Material: An Indoor Air Pollution Source Harming Metallic Objects . . . . . . . . . . . . . . . . 2287 Jingyi Shen

Infrared Thermography Applied to Inspection of Wood

Damages . . . . . . . . . . . . . . . . . . . . . . . . . . . . . . . . . . . . . 2293

Rui Pitarma, Lívia Pereira, and João Crisóstomo

Sustainable Preservation of the Built Environment: A Case Study of the Historic Centre of Oporto

Sílvia Alves and Juan Sendra

Improvement of Classroom Conditions and $\mathrm{CO}_{2}$ Concentrations Through Natural Ventilation Measures Reinforced with NBS Implementation

Jose Fermoso, Teba Torres, Miguel Ángel Antón, Alejandro Peña, Jesús Muñoz, Salustiano Torre, Teresa Batista, and Ricardo Osorio de Barros

An Improved Proposal for Using Laminar Copper as a Biocidal Material in Hospitals in Touch Surfaces: A Study on Volatiles 2311

Paula Aillón and Blanca Parga 
Environmental-Change-Related Impacts on Human Health:

Environmental and Occupational Health

Novel Sensor Chip for IoT/M2M- and LTE/3G-Network-Based

Water Quality Monitoring for Off-grid Water

Systems

Mokhtar Guizani, Shenxing Wang, Ryusei Ito, Masayoshi Johmen,

Ken Ushijima, Toshikazu Kawaguchi, and Naoyuki Funamizu

Stability Study of a Ratio-Dependent Eco-epidemiology Model

of the Salton Sea Using the Optimal Derivative

Fatiha Lassouani and Abdel Karim Ferouani

Assessment of the Bacterial Pollution in the Distribution

Network/Case Study of Souk Ahras Town, Algeria

Mohamed Amine Bensoltane, Lotfi Zeghadnia, Abdel Krim Guebail,

Ahmed Salah Araibia, and Lakhdar Djemili

An Integrated Framework of Environmental Physics

and Epidemiology: The Biometeorological Aspect of Thermal

Environment and Health Project (BeAT Heat).

Katerina Pantavou, Spyridon Lykoudis, Filippos Tymvios,

Emily Vasiliadou, Kleanthis Nicolaides, Chrysanthos Savvides,

Panayiotis Yiallouros, Constantinos Cartalis, and Georgios Nikolopoulos

Health Risk Assessment of Occupational Exposure

to Perchloroethylene and Trichloroethylene in Dry Cleaning

in Sfax City (Tunisia).

Fatma Omrane, Moncef Khadhraoui, Amine Abid, Mabrouka Mitigui,

Boubaker Elleuch, and Imed Gargouri

Assessment of Potential Health Hazards of Trace Elements

Contamination of Groundwater in a Shallow Aquifer: A Case Study

in Guenniche (Northern Tunisia) . . . . . . . . . . . . . . . . . . . . . . . . . . . . 2349

Nizar Troudi, Fadoua Hamzaoui-Azaza, Ourania Tzoraki,

and Mounira Zammouri

Effects of Outdoor Air Pollution on Human Health in Mohammedia,

"Morocco"

Rachida El Morabet, Abderrahmane Adoui El Ouadrhiri,

Roohul Abad Khan, Said Mouak, and Mohamed Aneflouss

Glycol Ethers in Water-Based Products: Determination and

Evaluation According to European Directives . . . . . . . . . . . . . 2365

Faycal Faidi, Samiha Hammami, Radhouane Chakroune,

and Abderrazek Hedhili 
Environmental-Change-Related Impacts on Human Health:

\section{Humain Health}

Influence of Monthly Temperatures on the Intra-annual Distribution of Autochthonous Malaria in Spain

Arturo Sousa, Julia Morales, Mark Vetter, Mónica Aguilar-Alba, and Leoncio García-Barrón

For a Better Literacy of Tunisians in Eco-health:

Leishmaniasis Case

Foued Maaoui, Imen Moumni, and Lasaad Mouelhi

“This Heat Is Killing": Perception of Heat Stress Among Elderly

Women in Ibadan, Nigeria

Tolulope Osayomi and Rebecca Chinweokwu Ugwu

The Potential of Green Areas Exposure on Increasing People's

Physical Activity

Silvestre García de Jalón, Aline Chiabai, Sonia Quiroga, Cristina Suárez,

Pablo Martínez, and Timothy Taylor

Genetic, Environmental, and Dietary Risk Factors of Colorectal

Cancer: A Case-Control Study in the Algerian East

Samira Negrichi and Salima Taleb

Relationship Between Anthropometric Parameters and Hypertension in an Algerian Adult Population According to BMI, Waist Circumference, and Waist circumference-to-Height Ratio

Salima Taleb, Kafila Boulaba, Ahlem Yousfi, Nada Taleb, Basma Difallah, and Samira Negrichi

Antimicrobial Activity of Oak Wood Against Nosocomial Acinetobacter Baumannii of Human and Animal Origin:

A One Health Approach

Muhammad Tanveer Munir, Christophe Belloncle, Florence Aviat,

Michel Federighi, Hélène Pailhoriès, and Matthieu Eveillard 


\section{About the Editors}

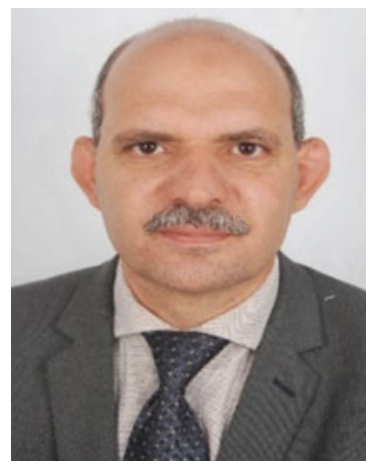

Mohamed Ksibi completed his Ph.D. in 1993 in Applied Chemistry at the University of Poitiers, France. He also gained the Habilitation (HDR) in Chemistry from the University of Sfax, Tunisia in 2003. He was appointed as a full Professor of Chemistry in 2009 at the Higher Institute of Biotechnology of Sfax (ISBS). His areas of research interest include removal and toxicology assessment of persistent organic pollutants in the environment (water and sediment/soil). He has supervised ten theses to completion and examined a further five Ph.Ds. He has also supervised fifteen MSc. theses. He has co-published about fifty-five papers, eight book chapters and co-edited a book (two volumes): Recent Advances in Environmental Science from the Euro-Mediterranean and Surrounding Regions. He is the co-editor-in-chief of the Euro-Mediterranean Journal of Environmental Integration (h-index 24). Dr. Ksibi was the Institute's Deputy Director of the ISBS from August 2011 until December 2017; he also served as the Director of the Department of Biotechnology and Health at ISBS from May 2008 until May 2011. He has been the chairman for the 1st in 2017 and the 2nd in 2019 of the Euro-Mediterranean Conference for Environmental Integration (https:// www.emcei.net). 


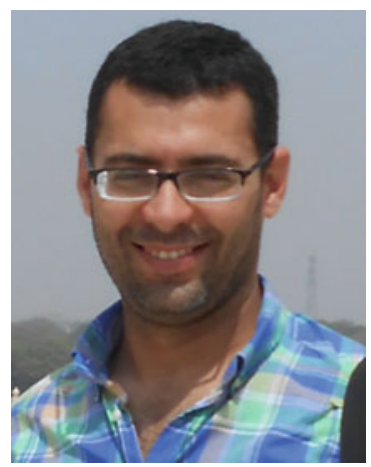

Achraf Ghorbal is the Vice-Director of the Higher Institute of Applied Sciences and Technology of Gabes-University of Gabes-Tunisia. Dr. Ghorbal obtained his M.Sc. in Processes and Materials Engineering (2003) and a Ph.D. in Chemistry of Materials (2006) from the University of Haute Alsace-Mulhouse-France. In 2007 he joined the French Atomic Energy Commission (Commissariat à l'énergie atomique) in Saclay-France, as a post-doctoral fellow. In 2008 he was hired as Assistant Professor, and then promoted to Associate Professor in Materials Sciences in 2015 at the University of Gabes-Tunisia. His research focuses on wastewater treatment, biopolymers, eco-materials and bio-composites for environmental applications. Dr. Ghorbal has authored and co-authored over forty scientific papers (peer-reviewed papers, books, book chapters, and patents), coordinated as a principal investigator in research and educational projects financed by national or international funds (e.g. Erasmus + CBHE promoted by the European Commission Agency; Indo-Tunisian joint project), and serves as peer reviewer for several high-impact journals (e.g. Waste Management; Environmental Science and Pollution Research). His work has been internationally recognized by several prestigious distinctions such as the Springer Best Reviewer Award (2017, Euro-Mediterranean Conference for Environmental Integration). Since 2019, Dr. Ghorbal is a managing and developmental editor of the Euro-Mediterranean Journal for Environmental Integration - a Springer Nature journal. 


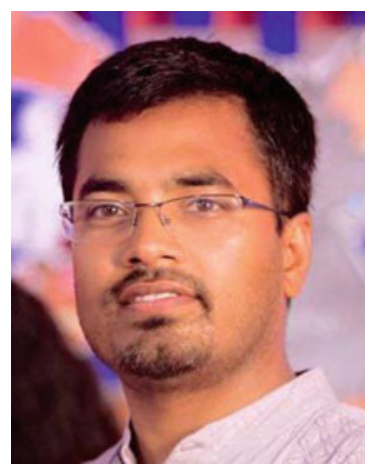

Sudip Chakraborty obtained a Doctorate in Chemical Engineering from University of Calabria, Italy. He currently works at the Laboratory of Transport Phenomena and Biotechnology, University of Calabria, Italy. He has successfully gained the Abilitazione Scientifica Nazionale-full professor in sector-ING-IND 24, and is also adjunct professor at Mindanao State University, the Philippines. Dr. Chakraborty has delivered several keynote/invited lectures and presentations in many international conferences all over the world. His major fields of interest are membrane separation, plasmonic nanoparticles, composite materials, energy and process intensification.

Dr. Chakraborty with h-index-30 has published more than ninety-five research publications in international SCI-indexed journals/book chapters, as well as more than seventy-five conferences. He has edited books and book chapters apart from several special issues in SCI-indexed journals. Dr. Chakraborty has also chaired technical sessions in many International Conferences. $\mathrm{He}$ is a member of several professional bodies such as the European Membrane Society, the Finnish Catalysis Society and the American Oil Chemists Society. He was also a visiting researcher at Massachusetts Institute of Technology (MIT), Boston, USA and Yale University, New Haven, Connecticut. Dr. Chakraborty is an associate editor of Groundwater for Sustainable Development (Elsevier) as well as chief editor and journal development editor of the Euro-Mediterranean Journal of Environmental Integration (Springer Nature). He has also edited special issues for Springer, Elsevier and MDPI journals.

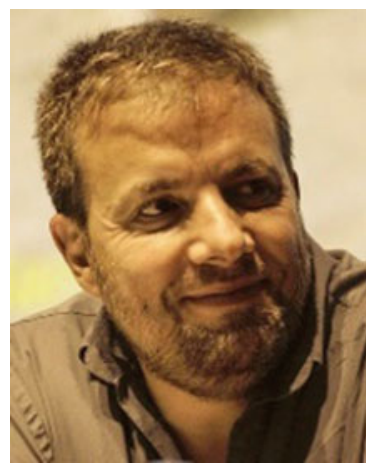

Helder I. Chaminé is a skilled geologist and Professor of Engineering Geosciences at the School of Engineering (ISEP) at the Polytechnic of Porto, Porugal. He has over thirteenth years' experience in multidisciplinary geosciences research, consultancy and practice. He studied geological engineering and geology (B.Sc., 1990) at the Universities of Aveiro and Porto (Portugal), respectively. He received his Ph.D. in geology at the University of Porto in 2000 and spent his postdoctoral research in applied geosciences at the University of Aveiro (2001-2003). In 2011 he received 
his Habilitation (DSc) in geosciences from Aveiro University.

Presently, he is Head of the Laboratory of Cartography and Applied Geology (LABCARGA) ISEP), Senior Researcher at the Centre GeoBioTec|U. Aveiro and Centre IDL/U.Lisbon, and is a member of the executive board of the MSc+BSc Geotechnical and Geoenvironmental Engineering (OE+EUR-ACE Label) and the Department of Geotechnical Engineering (ISEP). Currently, he belongs to the board of the Portuguese Association of Geologists (APG), Portuguese Committee of Environmental Geotechnics from SPG, and the International Association of Hydrogeologists-Portuguese Chapter. He was a board member of the SPG - Portuguese Geotechnical Society (2016-2020) the APGeom-Portuguese Association of Geomorphologists (2009-2013). Before joining the academy, he worked for over a decade in international projects for the geo-environment, mining, geotechnics and groundwater industry and/or academia. He was a consultant and/or responsible for over seventy projects in rock engineering, applied geology, hydrogeomechanics, slope geotechnics, mining geology, exploration hydrogeology, hard-rock hydrogeology, water resources, urban groundwater and applied mapping (Mozambique, Portugal and Spain).

He has co-authored over 200 publications in indexed journals, conference proceedings/full papers, book chapters, technical and professional papers. He co-edited over 14 special volumes, as well as is presently evolved in editing themed issues for 5 international journals. He has a wide activity as a referee for several international journals. He served as invited Expert Evaluator of Bologna Geoscience programme for DGES (Portugal) and Scientific Projects Evaluation for NCST (Kazakhstan) and NRF|RISA (South Africa), as well as Coordinator of "Geology on Summer/Ciência Viva" programme at ISEP for geosciences dissemination. He has been also active with teaching and supervising of many Ph.D., M.Sc. and undergraduate students.

Helder I. Chaminé has worked on the editorial boards of the Arabian Journal of Geosciences (SSG+Springer), Hydrogeology Journal (IAH+Springer), Geotechnical Research (ICE), Springer Nature Applied Sciences 
(Springer), Mediterranean Geoscience Reviews (Springer), Discover Water (Springer), EuroMediterranean Journal for Environmental Integration (Springer), Geosciences (MDPI), Revista Geotecnia (Portugal), and Geología Aplicada a la Ingeniería y al Ambiente (Argentina), among others. Currently, he is co-chair of the scientific committee of the 3rd International Workshop on Natural HazardsNATHAZ'22 (Terceira Island, Azores, May 2022) with the support of the Springer.

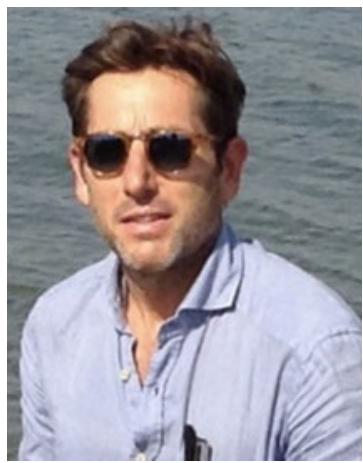

Maurizio Barbieri holds a degree in Geological Sciences (1994) and a Ph.D. degree in Earth Sciences (1998) from Sapienza University of Rome, (Italy). $\mathrm{He}$ is currently Associate Professor of Environmental Geochemistry and Hydrogeochemistry at Sapienza University of Rome (Italy). His current research focuses on the application of the geochemistry methodologies in the characterization of environmental problems. In particular he has studied the distribution of elements and isotopes in the Earth systems with emphasis on the use abundances and isotopic ratios in defining the interaction between different reservoirs (mantle, crust, atmosphere and hydrosphere). He also has related interests in environmental geochemistry and health, studying the role of toxic trace elements (e.g. As, B and $\mathrm{Hg}$ ), deriving from hydrogeochemical anomalies of natural origin, on water quality.

Maurizio Barbieri was environmental advisor (Hydrogeochemistry) for the International Project (20162019) SECOSUD II-Conservation and equitable use of biological diversity in the SADC region. The project was financed by the Italian Agency for Development Cooperation and implemented through Eduardo Mondlane University, South African National Park and Sapienza University of Rome.

He was scientific coordinator (2014-2016) for the geochemical model of the Vico Lake (Central Italy), with particular regard to environmental arsenic. Client: Regional Agency for Environmental Protection of Lazio.

He was scientific coordinator for the Water Unit of the International Project (2012-2014): Institutional Support to the management of Protected Areas in Albania, with funding from the International Union for the Conservation of Nature (IUCN). 


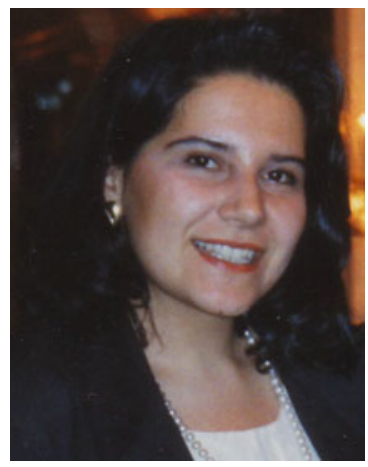

Giulia Guerriero received her Ph.D. at the University of Naples Federico II, Italy, where she is currently Associate Professor of Comparative Anatomy and Cytology and Chairman of the Comparative Endocrinology Laboratory, and is on the Advisory Board for the Center for Environmental Research. She performed postdoctoral work at the Department of Pharmacology, Thomas Jefferson University. Philadelphia, PA; the Department of Ob/Gyn, University of Illinois., Chicago, IL; and the Department of Physiology, Oregon Health Sciences, University of Portland, Oregon (USA). Her research efforts have focused on the correlation between oxidants and antioxidants in physiological defenses; on the role of steroid receptors in reproduction, and on the importance of barcoding in the evaluation of species-specific molecular responses. She is currently conducting research on the reproductive health effects of climate change, environmental pollution, sustainable economies and fisheries, and resilient systems. She has served on several working groups and technical committees and, as unit coordinator, in national and international projects. She has organized and participated in international conferences. Dr. Guerriero has published in relevant refereed international journals, and is currently serving as editor of several international journals. Further, she is a reviewer of international journal conference papers, books, research theses, national and international research proposals, as well as a BIES external examiner for UNESCO. She is a member of several national and international scientific societies and of the barcodingitaly consortium. Since 2011 she has been a representative of bilateral agreements between Federico II University and universities and research centers in Egypt, Algeria, Morocco, Malaysia and Japan. 


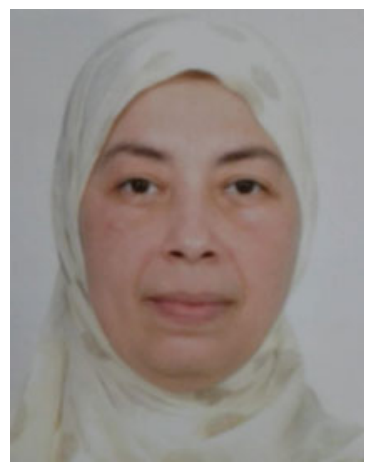

Olfa Hentati is an Associate Professor (2019) at the Higher Institute of Biotechnology (ISBS), University of Sfax. Since 2006 she has been a research member at the Laboratory Environemental engeneering et Ecotechnology (GEET-LR16ES19) at the National School of Engineers of Sfax (ENIS). She received her Diploma in Biology and Functional Exploration from the Faculty of Medicine at the University of Tunis, Tunisia, in 1988; her BSc and MSc in Cell Biology from the University of Poitiers, France in 1993 and 1994 respectively; and her Ph.D. in Cell Biology and Physiology from the University of Poitiers, France in 1999.

In 2017 Dr. Hentati gained her Habilitation in Biological Engineering. The focus of her research is on the use of terrestrial and aquatic organisms as bioindicators of chemical pollution, with particular emphasis to the influence of biological and environmental factors on the bioaccumulation of trace metals, raw and chemically treated dyeing wastewater, phenols and pharmaceuticals residues. She has wide experience on the ecotoxicological approach in arid to semi-arid areas, with particular emphasis to the characterization of key sentinel species to assess the early occurrence of biological disturbance of anthropogenic origin, and the toxicity and sensitivity to pollutants of arid-adapted organisms. She is associate editor on the Euro-Mediterranean Journal for Environmental Integrationand serves as a referee in several peer-reviewed scientific journals.

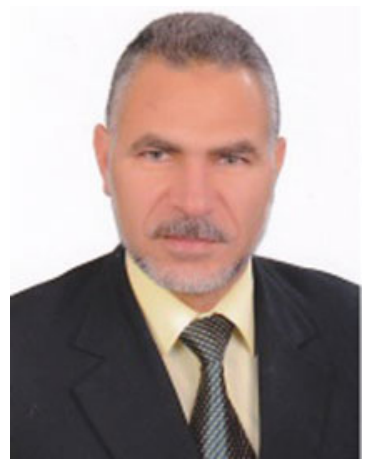

Abdelazim Negm is a professor of Hydraulics and Water Resources in the Water and Water Structures Engineering Department at the Faculty of Engineering at Zagazig University. He worked as a demonstrator in the Faculty of Engineering, Zagazig University in 1986 and continued there until he occupied the position of Vice Dean for Academic and Student Affairs. He worked for the Egypt-Japan University of Science and Technology (E-JUST) as a professor of Water Resources from December 2012 until September. 2016, and was chairperson of the Environmental Engineering Department at E-JUST from March 2013 until March 2016. 
Professor Negm has published more than 350 scientific papers in national and international Journals and conferences, and about fifty book chapters. He has participated in more than eighty-five conferences and was a keynote speaker at several national and international conferences. He has been awarded prizes for best papers three times. His research areas include hydraulics, hydrology and water resources. Currently, he is very interested in sustainability studies, sustainable development and the green environment in addition to water resources management.

Professor Negm is a member of IAHR and is the head of the Egyptian permanent scientific committee for Water Resources (115) for the promotion of associate and professorship positions for the cycle 2019-2022, and was the Vice Head for the cycle 2016-2019. He is a member of the editorial board of several scientific journals and international. conferences, associate editor-in-chief for IWTJ and was a member of the organizing committee of Oceanography 2015, and IWTC2013-IWTC2017. Additionally, he was Secretary General of the IWTC (www.IWTC.info) from 2013 until 2017. He was the head of the ZU committee for assessment of the scientific publications of ZU faculties until December 2018. Currently, he is organizing several contributed volumes to be published by Springer International Publishing during 2019/2020, after the successful publication of twelve contributed volumes by Springer Nature during the years 2016-2019, under the Handbook of Environmental Chemistry (HEC). Recently, four contributed volumes were published the under Springer Water series (2020). $\mathrm{He}$ is the editor-in-chief of EIJEST (Faculty of Engineering, Zagazig University), associate editor of IWTJ (IWTA) and EMJEI (Springer) and guest editor of $A J G S$-Springer. He is the principal investigator of several international projects. Currently, he is a member of the editorial board of the HEC series.

Professor Negm is listed in: Marquis' Who's Who? for over than ten years until now; IBC's 2000 Outstanding Intellectuals of the 21st Century; and the ABI Directory for his achievement in the fields of hydraulics and water resources. He has been nominated for many other awards from both IBC and ABI. 


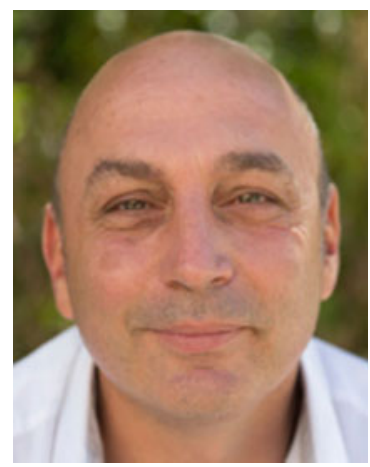

Anthony Lehmann was trained as an aquatic biologist and is now associate professor at the Institute for Environmental Sciences at the University of Geneva in Switzerland. He is a pioneer in combining Geographic Information Systems (GIS) with statistical modeling in the field of species distribution modeling, and has published and made available the first package called GRASP to build spatial predictions from point observations of plant and animal distributions. More recently, he coordinated the FP7 enviroGRIDS project, in which he concentrated on the use of hydrologic modeling to fill the gaps between scientific information and decision-making in the Black Sea catchment, by building capacity on Earth Observation and data-sharing approaches in the framework of the Global Earth Observation System of Systems (GEOSS). $\mathrm{He}$ is the coordinator of the H2020 GEOEssential project on Essential Variables derived from earth observations. He coordinates also a Swiss national research proposal entitled SWATCH21 on "Eco-hydrologic services of Swiss rivers and catchments under climate and landuse scenarios". Since the end of the enviroGRIDS project in 2013, Anthony Lehmann is orienting his research on spatially-explicit environmental assessment such as the Ecosystem Services and Nexus approach. Together with NatCap group from Stanford University, he wrote a review paper on "Lifting the barriers of online tools to address sustainability challenges". He collaborates also with the University Autonomous of Barcelona on the use of their nexus tool for "Multi-Scale Integrated Analysis of Societal and Ecosystem Metabolism" in complex socio-ecological systems. He is associate editor on the journal Environmental Sciences and Policywhere he is particularly editing the papers related to biodiversity and hydrologic issues with links with information technologies and modeling. $\mathrm{He}$ co-coordinated the edition of a MOOC on Ecosystem Services. He is repsonsible for a continuing education program on "Geomatics for a Sustainable Environment". 


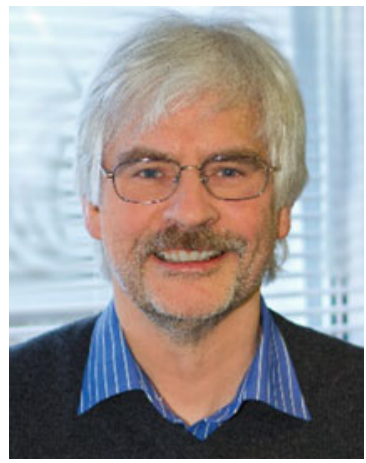

Jörg Römbke has a Ph.D. and a Diploma in Biology from the University of Frankfurt am Main. In 1994 he co-founded ECT Oekotoxikologie $\mathrm{GmbH}$ (located in Flörsheim/Germany) as a private contract research laboratory, where he is still one of two managing directors. Dr. Römbke is responsible for ecotoxicological effect and fate tests as well as the environmental risk assessment of chemicals (pesticides, heavy metals or pharmaceuticals) working both for the chemical industry and for national and international governmental authorities. He has published about 150 papers in indexed journals. Dr. Römbke specializes in the taxonomy, biogeography and ecology of soil fauna, in particular Oligochaeta such as earthworms and Enchytraeidae. He is involved in several ecological and ecotoxicological field-studies in Germany, other European countries, Brazil (Amazonas, Parana) and North Africa, most recently the EU-FP7 project EcoFINDERS. He is especially interested in the development and standardization of ecotoxicological test methods as well as in the international harmonization of methods for biological soil monitoring, for example, serving as chair of ISO TC 190/SC4 (the committee responsible for biological methods).

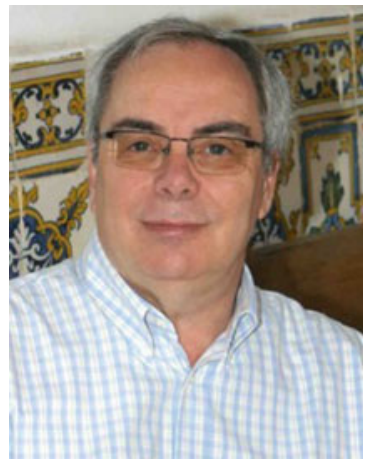

Armando Costa Duarte obtained a Chemical Engineering five-year degree at the University of Oporto in 1977, a Ph.D. in Public Health Engineering at the University of Newcastle-upon-Tyne in 1981, and the Habilitation in Chemistry at the University of Aveiro in 1989. He has over thirty-five years of internationally recognized experience in analytical chemistry, qualimetrics and analytical quality assurance aiming at obtaining experimental data to support decisions on food safety, health and environmental protection, as well as sustainable development. 
His research has made significant contributions in the field of distribution, availability and the fate of chemical compounds in different environmental compartments, chemical speciation and dynamics in coastal environments, and the characterization of natural organic matter and its interaction with contaminants of environmental significance. Armando da Costa Duarte has coordinated over thirty Ph.D./Master students and is currently coordinating the work of several $\mathrm{Ph} . \mathrm{D}$. and MSc students in their development of scientific and technological knowledge of excellence on analytical chemistry, qualimetrics and analytical quality assurance. He has either participated or coordinated over seventeen research projects funded by international and national funding agencies. In addition to his ten published books and more than thirty book chapters, Armando da Costa Duarte has over 560 significant peer-reviewed publications. He has also been on the editorial/review panels of reputed international and national scientific journals, and has contributed more than 200 oral/poster communications in scientific meetings. He has received two awards and/or honors. In professional activities he has interacted with 1021 collaborator(s) as co-author of scientific papers. In January 2020 he had an h-index ranging from 53 on SCOPUS to 65 on Google Scholar and total citations ranging from 11987 (SCOPUS) to 16684 (Google Scholar). More details can be found at https://orcid.org/ 0000-0002-4868-4099 and http://www.cesam.ua.pt/ aduarte.

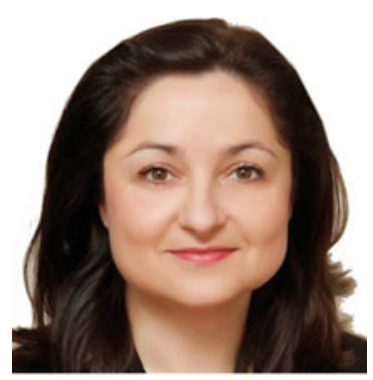

Elena Xoplaki is an expert in Mediterranean climate change research. She has conducted analysis on extremes (heat waves, floods, droughts, etc.), paleoclimatology, climate impacts on societies, climate reconstructions/ model comparisons and the influence of circulation on the European and Mediterranean climates. She has participated in and coordinated several European, Swiss and US research projects. From August 2011 she has been awarded an Akademischer Rat position at the Justus-Liebig-University Giessen in Germany. Over the past years, Dr. Xoplaki was strongly involved in the Climate Change and History Research Initiative at Princeton University: "A comparative approach to 


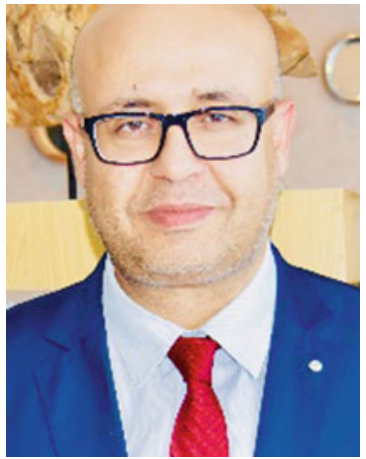

climate, environment and society in the Eastern Mediterranean: Towards understanding the impact of climate on complex societies." Her current work also deals with renewable energies and wind power production and climate change for human health aspects. She is also a Steering Committee member of the network of "Mediterranean Experts on Climate and Environ* mental Change (MedECC): Towards an improved scientific assessment of climate change and its impact in the Mediterranean Basin." She has more than seventy peer-reviewed publications and a h-index of 38 .

Nabil Khélifi holds a B.Sc. in Natural Sciences and a M.Sc. in Earth \& Environmental Sciences from the University of Sfax in Tunisia (2004). He received fellowships from the global change System for Analysis, Research and Training (START) in 2005 and the German Academic Exchange Service (DAAD) from 2006 to 2010 to continue with his Ph.D. studies in Marine Geosciences at the University of Kiel in Germany. After his Ph.D. in 2010, Dr. Khelifi received a postdoctoral research grant from the German Science Foundation (DFG) to start his self-designed research projects at the GEOMAR-Ocean Research Centre in Kiel, Germany on reconstructing past changes in oceanography and climate in the North Atlantic and the Mediterranean Sea using marine sediment samples retrieved by the International Ocean Drilling Program (IODP) and applying foraminiferal and geochemical proxy methods. He published his research work in some reputable journals. Dr. Khelifi also received funding from the European Science Foundation (ESF) and some European universities to co-organize two workshops on Pliocene climate in Bordeaux, France (2009) and Bristol, UK (2013). He also received the Swiss Government Excellence Scholarship (SGES) to continue with his research projects at ETH Zurich, Switzerland in early 2014. However, he decided in March 2014 to pursue his career as a publishing editor with Springer, a part of Springer Nature in Heidelberg, Germany. He is mainly responsible for developing Springer's publishing program in the Middle East \& North Africa (MENA). The program currently consists of developing eighteen journals and publishing about 
forty scientific books every year. In January 2017 he was promoted to Senior Publishing Editor with Springer. Dr. Khelifi also helps researchers in MENA countries publish their work by delivering educational seminars for authors, reviewers and journal editors to help improve publication output and quality. Dr. Khelifi is also a Visiting Lecturer at the University of Carthage, Tunisia and King Saud University, KSA giving MSc and $\mathrm{Ph}$.D. courses in geo-communication/-presentations and techniques of paper publishing, as well as career development training and professional development/ soft skills workshops. Recently, Dr. Khelifi has been awarded with the 2016 Africa Green Future Leadership Award in recognition of his work contributing to sustainable development through advancing science and promoting publications in Africa and the Middle East.

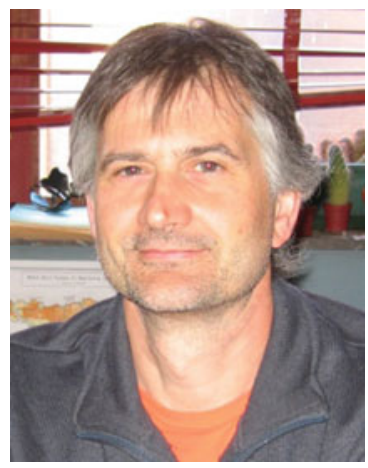

Gilles Colinet (Belgian, born 1967) is assistant professor at Liege University (Gembloux Agro-Bio Tech). In 1991 he graduated as an engineer in agronomy with a specialization in soil science. His professional career began with a two-year cooperation work in Mali, a few month research at Liege University dedicated to modeling the global carbon cycle, and two years of technical and administrative support on GIS and databases for the Agriculture General Direction of the European Commission.

In 1997 he returned to Gembloux Agro-Bio Tech as a research and teaching assistant under the supervision of Prof. Laurent Bock. The title of his Ph.D. (in French) was: "Metallic trace elements in soils: Contribution to knowledge of the factors of their spatial distribution in the Belgian silt loess" (defense in 2003).

After studying the natural background, he focused his researches into trace elements on the relationships between soil, water and plants - the bioavailability and mobility of elements - and mapping in contaminated environments, among which were the calaminary sites in Belgium and the copper ecosystems in Katanga.

Simultaneously, Gilles Colinet developed research on: (1) risk of contaminations of the food chain in urban gardens, the management and rehabilitation of brownfields and soil remediation; (2) monitoring of soil 
quality in croplands and forests in relationship with the quality of the hydrosphere (nitrate, phosphorus, pesticides ...); and (3) the integration of digital soil maps and point databases to build soil reference systems in Southern Belgium.

Gilles Colinet teaches applied soil science at Liege University to bioengineers, geologists and geographs, as well as in specialized Master degrees. He also coordinates a formation about the management of polluted sites in continuing education.

Gilles Colinet has supervised numerous Master theses in Belgium and overseas, seven Ph.D.s-plus seven others at the present time - and twenty or so research projects in Belgium, the Democratic Republic of Congo, Morocco, Burkina Faso, China, the Philippines and Bolivia.

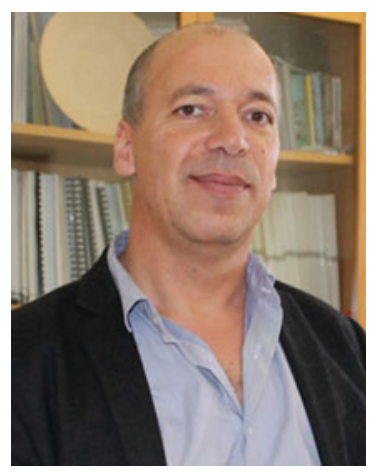

João Miguel Dias holds a Ph.D. in Physics and is Associate Professor with Habilitation in the Department of Physics at the University of Aveiro, where he is the current Director. He founded and leads the Estuarine and Coastal Modeling Division (http://www.nmec.eu/), and is a researcher at the Centre for Environment and Marine Studies) (CESAM), where he is co-coordinator of the Integrated Environmental Systems thematic line. With nearly thirty years of professional experience, he is a specialist in the numerical modeling of physical processes in estuarine and coastal zones. He has participated and coordinated several national and international research projects and has extensive experience in consulting for public and private organizations. He is the editor and reviewer of a large number of international journals, and has integrated project and scholarship evaluation panels in the field of marine science for various national and international agencies. He is the author of over 150 papers in international journals in the areas of environmental sciences and oceanography, and has supervised a significant number of postdoctoral researchers and Ph.D. and M.Sc. students. 


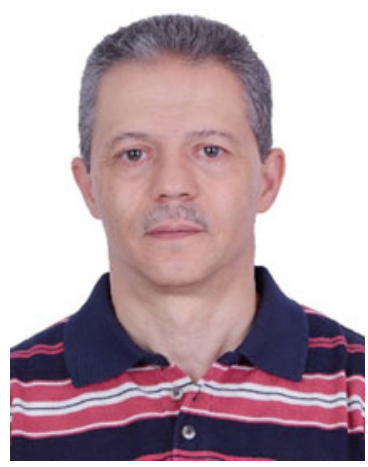

Imed Gargouri is an associate professor at the Faculty of Medicine, Sfax University since February 2012. He is the holder of (i) a MD from Sfax University since 1996, (ii) a National Diploma in occupational medicine since September 2000, (iii) a Master's Degree in environmental and health research methods from the University of Grenoble (France) since September 2002, (iv) a Ph.D. in toxicology and occupational health risk assessment from Lille University (France) in 2009. He is also a researcher at the Laboratory of Environmental Engineering and Ecotechnology (National School of Engineering, Sfax University). His research themes deal with (i) chemical risk assessment, (ii) occupational toxicology and (iii) environmental health impacts.

Professor Gargouri has published about twenty-five research papers at the national and international levels, two books and five book chapters mainly in the fields of the environment, chemical risk assessment, occupational toxicology, environmental health impacts and occupational health. He is also a reviewer for several international specialized journals, has chaired several international and national conference sessions and is a member of several scientific committees.

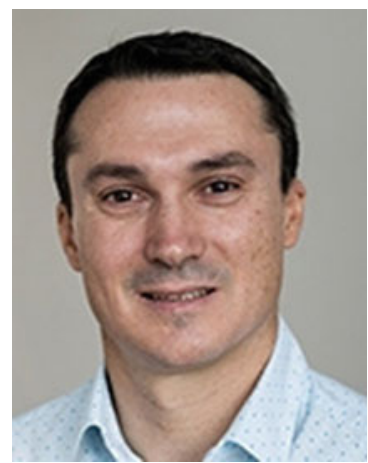

Eric D. Van Hullebusch received his Ph.D. (Aquatic Chemistry and Microbiology) from Université de Limoges (France) in 2002. From November 2002 until October 2004 he was a Marie Curie Postdoctoral fellow at Wageningen University \& Research (the Netherlands) where his research focused on the optimization of anaerobic granular sludge reactors by studying the speciation, bioavailability and dosing strategies of trace metals. In 2005, he was appointed as associate professor in biogeochemistry of engineered ecosystems at Université Paris-Est (France). In 2012, Eric D. van Hullebusch obtained his Habilitation qualification in Environmental Sciences from Université Paris-Est (France). The title of his Habilitation thesis is "Biofilms in the environment: 


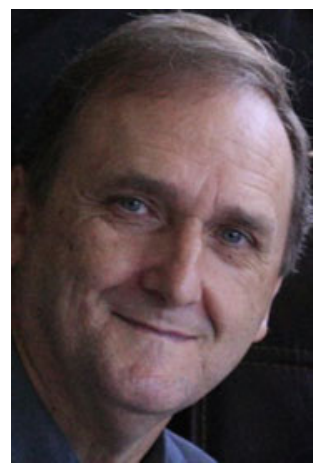

from anaerobic wastewater treatment to material bioweathering". From September 2016 until August 2018, he worked at IHE Delft as chair professor in Environmental Science and Technology and head of the Pollution Prevention and Resource Recovery chair group. In September 2018 he joined Institut de Physique du Globe de Paris (France) as full professor in Biogeochemistry of engineered ecosystems.

Benigno Sánchez Cabrero was born in Iscar (Valladolid), Spain, in 1955. He holds a Ph.D. in Chemistry and a B.Sc. Degree in Biology from the Autonomous University of Madrid. He also has a Diploma in Environmental Engineering, and others in Territorial Zoning and Environment from the University of Valencia.

From 1985, and currently, Dr. Sánchez is a senior researcher at the CIEMAT (Centro de Investigaciones Energéticas Medioambientales y Tecnológicas).

$\mathrm{He}$ has been the Head of the Environmental Applications of Solar Radiation to Air Group in the PSA (Plataforma Solar de Almería) from 1990 to 2014. From 2014 he is the Head of Analysis and Photocatalytic Treatment of Pollutants in Air (FOTOAIR) in the Renewable Energy Division of CIEMAT.

Benigno Sánchez Cabrero has thirty-four years of $R \& D$ expertise, participated in thirty-seven national and international $\mathrm{R} \& \mathrm{D}$ projects funded by competitive public programs, and has been the head researcher in twenty-three of them. He has been involved in nine $R \& D$ contracts with businesses of particular relevance.

$\mathrm{He}$ is the co-author of sixty-five scientific-technical publications, and more than one hundred contributions to congresses, courses, seminars and conferences.

$\mathrm{He}$ directed seven Ph.D. theses with two more currently underway, plus nineteen Degree projects in Environmental Science and Chemical Engineering at the UAM, URJC, and UCM in Madrid.

$\mathrm{He}$ is the first author of a patent and a utility model.

Benigno Sánchez Cabrero has been the national representative to COST 612 (Brussels) and Task Forces related to the effects of air pollution on ecosystems (UN, Geneva). 
He is a referee for Applied Catalysis B: Environmental, Building and Environment, and CYTED, COLCIENCIAS, ANPCyT Evaluator among others.

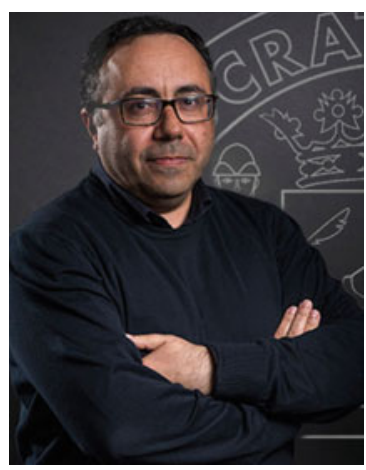

Settimio Ferlisi is Associate Professor of Geotechnics at the University of Salerno (UNISA) in Italy where he currently teaches "Geotechnics" and "Foundations". The results of his scientific activity are testified by numerous publications as well as by his participation in the Center of Excellence on Hydrogeological Risk of UNISA, three projects of relevant national interest (in one case as coordinator of the research unit), and a EU-funded research project. He is on the Board of Professors of the Ph.D. in "Risk and Sustainability in Civil, Architectural and Environmental Engineering Systems" with administrative headquarters at UNISA, a member of the Scientific Committee of the International School on "Landslide Risk Assessment and Mitigation" (LARAM), and head of the Geotechnical Laboratory of the Department of Civil Engineering of UNISA. He is also chief editor of the Euro-Mediterranean Journal for Environmental Integration (Springer) and a member of the editorial board of Geoenvironmental Disasters (Springer).

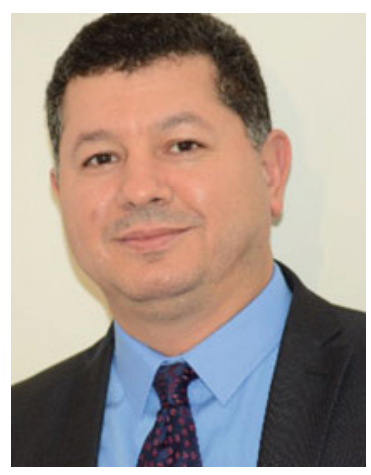

Chedly Tizaoui CEng, FIChemE, FHEA is an Associate Professor in Chemical Engineering at the College of Engineering, Swansea University, United Kingdom. He obtained his first degree in Chemical Engineering (six-year path) from the National School of Engineering at Gabes (ENIG), Tunisia, his MSc from INP Toulouse France and his Ph.D. in Chemical Engineering from the University of Bradford UK. Dr. Tizaoui has been the head of the Chemical and Environmental Engineering Portfolio at Swansea University, and he has research interests in Advanced Oxidation Processes (AOPs) and separation technologies to treat water and wastewater. Examples of technologies he is researching include ozone, UV, and nonthermal plasma, membranes, adsorption and bio-flocculation. He develops and employs these technologies to eradicate contaminants of health and environmental significance such as emerging contaminants, pharmaceuticals, oils, landfill leachates, or phosphates and arsenic. Throughout his academic 


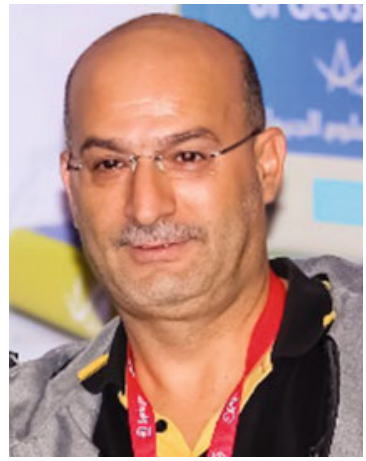

career, Dr. Tizaoui has devoted himself to research and scholarly activities and has played a significant role in contributing towards various fundamental and applied collaborative research programs. He has supervised to successful completion over twenty Ph.D. and postdoctoral researchers and has published over one hundred papers in peer-reviewed journals and international conferences, as well as authoring technical reports for several organizations. His research into water treatment technologies has been funded by major funding bodies including the UK Engineering and Physical Sciences Research Council; the Royal Society; the Royal Academy of Engineering, and industry. He is associate editor of Ozone: Science and Engineering, and the Euro-Mediterranean Journal for Environmental Integrationand sits on the editorial boards of several peer-reviewed scientific journals, and has also been a reviewer for many international scientific journals and funding bodies around the world. He is member of the International Ozone Association and member of the EU Ph.D. School of Advanced Oxidation Processes.

Amjad Kallel is an Asscociate Professor of Environmental Geology. He holds a B.Eng. in Georesources and Environment (1998) from the University of Sfax (Tunisia), and an MSc degree and a Ph.D. degree in Georesources and Environment (2004) from Hokkaido University (Japan). He joined Venture Business Laboratory (VBL) at Akita University, Japan (2005-2006) as a researcher focusing on refining and recycling technologies for the recovery of rare elements from natural and secondary sources. Back in Tunisia, he worked at the University of Gabes from 2006 to 2011, where he contributed to the elaboration of teaching programs at the Higher Institute of Water Sciences and Technologies of Gabes. Since 2011, he has joined the Sfax National School of Engineering (University of Sfax, Tunisia). There, he has also been involved in various research projects related to environmental geology and environmental geotechnics. Dr. Kallel has organized many prestigious workshops, seminars and international conferences. In 2016, Dr. Kallel joined the Arabian 
Journal of Geosciences and the Euro-Mediterranean Journal for Environmental Integration (Springer) as both a chief editor and managing editor, respectively.

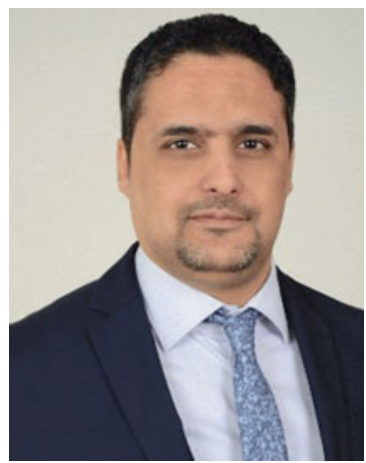

Sami Rtimi is a photo-chemist with a strong background in materials science and microbiology. He was awarded a Ph.D. in Chemistry and Chemical Engineering from the Swiss Federal Institute of Technology-EPFL and a Doctorate in Biological Sciences from the University of Carthage (Tunisia). $\mathrm{He}$ is investigating the structure-reactivity relationship of functional/smart materials for environmental (indoor and outdoor) and biomedical applications. With an h-index of 24, he published more than one hundred articles in peer-reviewed journals, patents, several book chapters and presented numerous communications at international meetings. He is editor, guest-editor and regular reviewer for several journals. Sami is an international grants reviewer and Ph.D. programs evaluator. He is also active in some NGOs to promote water and health solutions in Least Developed Countries (LDCs).

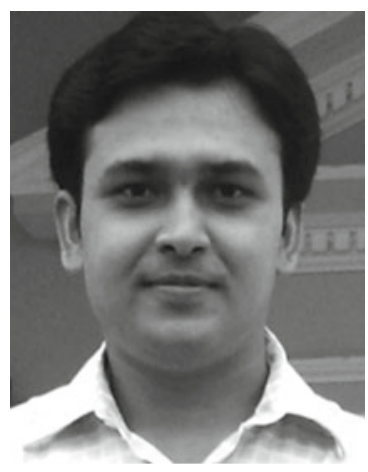

Sandeep Panda received his BSc degree with honors in Zoology (2006) from Utkal University, his M.Sc. degree in Biotechnology (2008) from Ravenshaw University and his Ph.D. degree in Life Sciences (2015) from North Orissa University, India. He is currently working as an assistant professor at the Department of Mining Engineering (Mineral-Metal Recovery and Recycling Research Group), Suleyman Demirel University, Turkey. His main research areas include bio-hydrometallurgical and bio-mineral processing for metal extraction from primary and secondary resources, bio-desulphurization, bio and chemical approaches for mine water treatment, and the application of eco-friendly approaches for sustainable mineral-metal waste recycling and management. In 2008, Dr. Panda worked as a research trainee at Bhabha Atomic Research Centre, India, for partial completion of his Masters degree and thereafter joined CSIRInstitute of Minerals and Materials Technology, India in 2009 as a project assistant. In 2012 he was selected as the prestigious CSIR-Senior Research Fellow (direct 
scheme) by the Council of Scientific and Industrial Research (CSIR), Government of India. He has been involved (as principal/co-principal investigator and as team member) in many $R \& D$ and industrial research projects (at both national and international levels) since 2009. As of 2019, he has published thirty-seven international journal papers, and four book chapters of high quality and impact that have received nearly 650 citations (h-index-15). His research works have invited the attention of several press and media outlets. $\mathrm{He}$ is an active member of several prestigious professional bodies and a technical/scientific committee member in a number of reputed International conferences. Dr. Panda has served as a reviewer in over thirty reputed international journals and is currently serving as: (1) associate editor of the Euro-Mediterranean Journal of Environmental Integration (Springer Publications); and is an editorial board member of: (2) Frontiers in Microbiology (Frontiers Publications); (3) Frontiers in Earth Science (Frontiers Publications); (4) Frontiers in Environmental Science (Frontiers Publications); and (5) review editor of the section Microbiological Chemistry and Geomicrobiology (Frontiers Publications). He has edited two reputed joint-editorial books: (1) Environmental Microbial Biotechnology (Springer Publications, Switzerland, 2015); and (2) Applied \& Industrial Biotechnology (2nd edition, Nirmal Publications, India, 2017). He has also received several prestigious academic awards such as: (1) "The Best Research Scholar Award" by CSIRInstitute of Minerals and Materials Technology, India (2010); (2) "The Best Hindi Essay writing Award on Environment" from CSIR-Institute of Minerals and Materials Technology, India (2010); (3) The prestigious "MISRA Award-The Best Paper Published Award 2012" by the Indian Institute of Mineral Engineers (IIME), India (2013); (4) “TÜBİTAK-2216 International Post Doctoral Scholarship-2015" (Research Fellowship Program for International Researchers) from the Scientific \& Technological Research Council of Turkey, 2015-2016; and (5) The prestigious "Young Scientist Award" by Odisha Bigyan Academy (OBA), Odisha, India in 2017. 


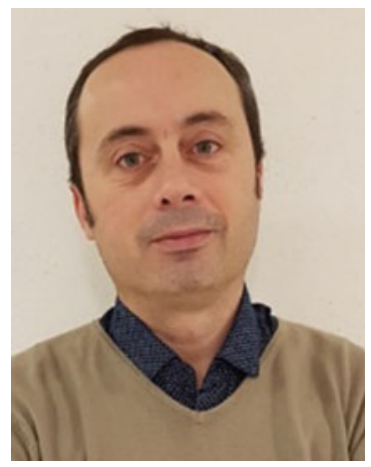

Philippe Michaud is a Professor of Biochemistry at the head of the Biological Engineering Department of Polytech Clermont Ferrand, a school of engineering of the Clermont Auvergne University (France). A Doctor in Microbiology, Enzymology and Bioconversion, since 2005 he has led a research group entitled "Bioprocesses, Biorefinery, Biopolymers and Biosourced materials" at the Institut Pascal (UMR CNRS 6602) consisting of three associate professors and one technician. His scientific skills center on the development of bioprocesses for obtaining poly- and oligosaccharides from various sources (terrestrial plants, agronomic by-products, macroalgae, microorganisms) and analysis of structure-function relationships. He has published 147 research papers and reviews in international peer-reviewed journals in the field of biotechnology and bioprocesses applied to polysaccharides (h-index 34). Professor Michaud is the inventor or co-inventor of twelve patents, three of them with industrial exploitation. $\mathrm{He}$ is the author or co-author of nine book chapters. He has been the advisor or co-advisor for eighteen Ph.D. students. Since 2005, he has been in charge of more than ten national and international research projects, funded or co-funded by industry.

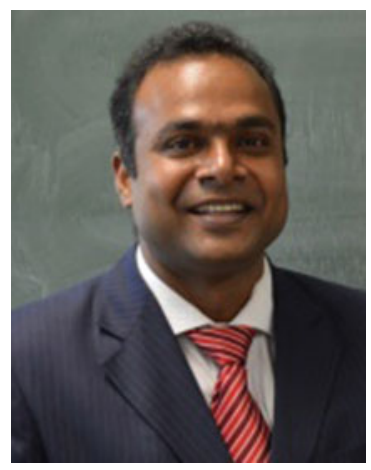

Jaya Narayana Sahu was born in 1976. He received a B.Tech. (Chemical Engineering) from Berhampur University, India and a Ph.D. (Chemical Engineering) from the Indian Institute of technology (IIT) in Kharagpur, India. Dr. Jaya has more than fifteen years of teaching, research, consultancy and projects experience. $\mathrm{He}$ is the author/co-author of more than 140 papers (Scopus h-index 40). He is presently working at the University of Stuttgart, Institute of Chemical Technology, Faculty of Chemistry, Stuttgart, Germany under the prestigious Alexander von Humboldt Foundation senior research fellowship. He is the chief editor (Topic 7: Smart technologies for environmentally-friendly energy production) of the Euro-Mediterranean Journal for Environmental Integration (Springer). 

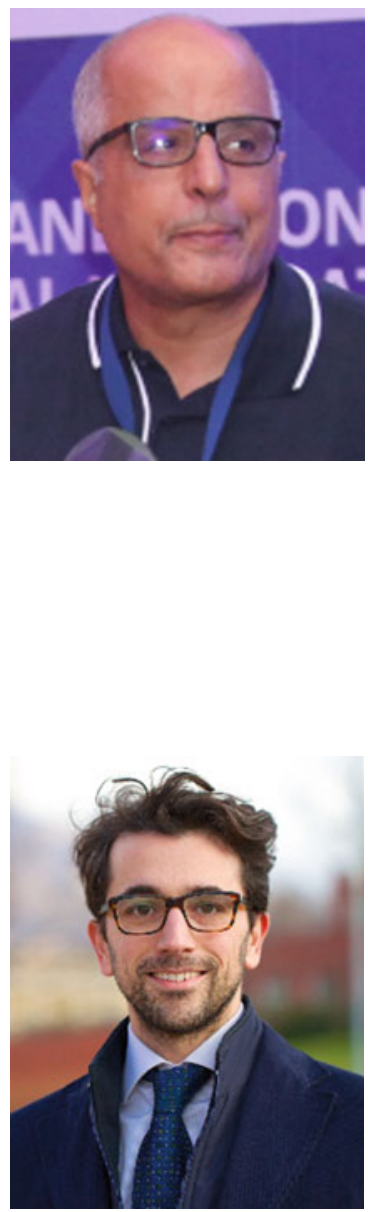

Mongi Seffen gained a Ph.D. in Applied Chemistry at Poitiers, France (1986), and is a full professor of chemistry since 2002 . He has published sixty papers in international refereed journals, six patents in the field of waste oil recovery, waste water treatment by the biosorption process and biofuel production starting from biomass. Professor Seffen is the supervisor of ten $\mathrm{Ph} . \mathrm{D}$. theses and twelve graduate theses. He is the local coordinator of two FP7 Projects, SOWAEUMED and FP4BATIW, and several bilateral projects: Tunisian-Moroccan; Tunisian-Egyptian; DGRST; ERASMUS $^{+}$......; and is associate editor for the Euro-Mediterranean Journal for Environmental Integration. He has organized several workshops and scientific meetings. He is a specialist in: waste water treatment, biomass valorization; biofuels; and waste oil recovery catalysis.

Vincenzo Naddeo is Director of the Sanitary Environmental Engineering Division (SEED) at the Department of Civil Engineering of the University of Salerno (Italy) where he drives research activities in the Environmental Engineering fields. He was a professor in visit at the University of Washington (2009) and Yamaguchi University (2016) as well as a visiting scientist at several foreign research institutions where he collaborated with high-ranking professors. Professor Naddeo is founder and general chair of the international conference series WaterEnergyNEXUS, and coordinator of its International Scientific Advisory Board. Since 2014 Prof. Naddeo holds the Italian National Scientific Qualifications for full professor positions in the academic field 08/A2 (Sanitary and Environmental Engineering).

Professor Naddeo's research focuses on advanced water/wastewater treatment, characterization and control of environmental odours and environmental impact assessment (EIA). He developed advanced biological processes for wastewater treatment and control of emerging contaminants, novel ultrasound-based technological processes for the treatment of environmental matrices (solid, liquid and gaseous) and biotechnologies for wastewater re-use with simultaneous energy production within the circular economy. In addition to 
the topics listed above, Professor Naddeo has published works on membrane bioreactors (MBRs), water/ wastewater disinfection and disinfection by-products (DBPs), Advanced Oxidation Processes (AOPs), river water quality characterization, remediation of contaminated soil and marine sediments, management and treatment of the organic fraction of solid waste, strategic environmental assessment (SEA) and recently on environmental technologies for the sustainable development of smart cities.

At the Department of Civil Engineering Prof. Naddeo teaches: "wastewater treatment plants", "environmental impact assessment", "energy and environmental sustainability" and "pollution phenomena and control of environmental quality". He is the coordinator of several international and national research projects, a supervisor of Ph.D. students, and a member of the scientific boards of several national and international conferences where he was often invited as plenary or keynote speaker.

$\mathrm{He}$ is associate editor of Water Environmental Research (Wiley), the Euro-Mediterranean Journal for Environmental Integration (Springer) and of the Earth, Frontiers for Young Minds. He presently serves on the editorial board of several ISI journals including Desalination (Elsevier), Scientific Reports (Nature Research), PeerJ (Life, Bio, Environment \& Health Sciences), Frontiers in Bioengineering and Biotechnology, Water (MDPI) and Bioengineered (Taylor \& Francis). Professor Naddeo is also actively involved in a variety of scientific organizations, funding agencies, and European networks.

He holds four patents on water and wastewater treatments by sonolysis and one patent on the novel electronic nose (e.Nose). From 2018 Prof. Naddeo has been CEO and co-founder of Sponge s.r.l., a spin-off of the University of Salerno working in the environmental technology field. He has (co-)authored over 200 refereed publications in ISI journals, congress proceedings and book volumes. He is co-editor of the book Odour Impact Assessment Handbook (John Wiley \& Sons) as well as editor of several Italian books. 